\title{
Serum and Plasma Tumor Necrosis Factor Alpha Levels in Individuals with Obstructive Sleep Apnea Syndrome: A Meta-Analysis and Meta-Regression
}

\author{
Mohammad Moslem Imani ${ }^{1}$, Masoud Sadeghi ${ }^{2}$,, Habibolah Khazaie ${ }^{3}$, Mehrdad Emami $^{4}$, \\ Dena Sadeghi Bahmani ${ }^{3,5,6,7}$ and Serge Brand $3,5,6,8,9, *(D)$ \\ 1 Department of Orthodontics, Kermanshah University of Medical Sciences, 6713954658 Kermanshah, Iran; \\ mmoslem.imani@yahoo.com \\ 2 Medical Biology Research Center, Kermanshah University of Medical Sciences, 6714415185 Kermanshah, \\ Iran; sadeghi_mbrc@yahoo.com \\ 3 Sleep Disorders Research Center, Kermanshah University of Medical Sciences, 6719851115 Kermanshah, Iran; \\ hakhazaie@gmail.com (H.K.); dena.sadeghibahmani@upk.ch (D.S.B.) \\ 4 Students Research Committee, Kermanshah University of Medical Sciences, 6715847141 Kermanshah, Iran; \\ master_com63@yahoo.com \\ 5 Center for Affective, Stress and Sleep Disorders, University of Basel, Psychiatric Clinics, \\ 4001 Basel, Switzerland \\ 6 Substance Abuse Prevention Research Center, Kermanshah University of Medical Sciences, \\ 6715847141 Kermanshah, Iran \\ 7 Departments of Physical Therapy, University of Alabama at Birmingham, Birmingham, AL 35209, USA \\ 8 Department of Sport, Exercise and Health, Division of Sport Science and Psychosocial Health, \\ University of Basel, 4052 Basel, Switzerland \\ 9 School of Medicine, Tehran University of Medical Sciences, 1416753955 Tehran, Iran \\ * Correspondence: serge.brand@upk.ch
}

Received: 22 April 2020; Accepted: 9 June 2020; Published: 12 June 2020

\begin{abstract}
Background: Obstructive sleep apnea syndrome (OSAS) is associated with a variety of inflammatory factors. Specifically, proinflammatory cytokines appear to be associated with the pathogenesis of OSAS. Methods: For the present meta-analysis and meta-regression on serum and plasma tumor necrosis factor alpha (TNF- $\alpha$ ) levels in individuals with and without OSAS, we performed a systematic search without any restrictions of the PubMed/Medline, Scopus, Cochrane Library, and Web of Science databases to find relevant articles published up to 1 February 2020. Results: Fifty-five (adults: 29 studies on serum and 17 studies on plasma; children: 4 studies on serum and 5 studies on plasma) were included and analyzed. Always compared to age-matched healthy controls, the pooled MDs were as follows: adults, serum: $10.22 \mathrm{pg} / \mathrm{mL}$ (95\% CI $=8.86,11.58 ; p<0.00001)$; adults, plasma: $5.90 \mathrm{pg} / \mathrm{mL}(95 \% \mathrm{CI}=4.00,7.80 ; p<0.00001)$; children, serum: $0.21 \mathrm{pg} / \mathrm{mL}(95 \% \mathrm{CI}=0.05,0.37 ; p=0.01)$; children, plasma: $5.90 \mathrm{pg} / \mathrm{mL}(95 \%$ $\mathrm{CI}=4.00,7.80 ; p<0.00001$ ). Conclusions: Compared to healthy and age-matched controls, adult individuals with OSAS had significantly higher serum/plasma TNF- $\alpha$ levels. For children with OSAS, significantly higher levels were observed for TNF- $\alpha$ in serum but not in plasma.
\end{abstract}

Keywords: obstructive sleep apnea syndrome; cytokine; tumor necrosis factor alpha; serum; plasma; meta-analysis; meta-regression

\section{Introduction}

Obstructive sleep apnea syndrome (OSAS) is a common sleep-related breathing disorder. It is estimated that $4 \%$ of both female and male adults suffer from OSAS [1]. Specifically, about $2 \%$ 
middle-aged individuals (30-60 years) suffer from OSAS, and prevalence rates increased by $30 \%$ to $50 \%$ in adults with overweight and obesity [2,3]. Typically, in individuals with OSAS, the repetitive obstruction of the upper airway during sleep leads to hypoxemia, arousals, intermittent snoring, episodes of complete apnea, and to increased daytime sleepiness as a result of non-restoring sleep [4]. To define OSAS, both objective and subjective measurements are applied: While self-rating questionnaires such as the STOP-Bang [5,6] allow a rough screening, polysomnography is the gold standard: OSAS are defined as the Apnea-Hypopnea Index (AHI) $>5$ events per hour [7].

People with objectively assessed OSAS are at increased risk to suffer from atherogenesis [8], vascular dysfunction [9], congestive heart failure, hypertension, atrial fibrillation, nocturnal arrhythmias, stroke, pulmonary hypertension, and metabolic syndrome [10,11].

As regards the immune system, the tumor necrosis factor alpha (TNF- $\alpha$ ) is a common cytokine secreted by adipocytes and the mononuclear-macrophage system [12], which regulates the immune system, induces inflammation, and participates in the regulation of fat metabolism [13]. More specifically, several inflammatory cells secrete proinflammatory cytokines such as TNF- $\alpha$. Increased TNF- $\alpha$ concentrations can cause inflammatory responses such as neutrophil recruitment, tissue destruction, neovascularization [14], oxidative stress, systemic inflammation, autonomic nervous system dysfunction, atherosclerosis, and aging [15]. Further, highly increased TNF- $\alpha$ concentrations appear to be causally associated with the pathogenesis of diseases such as metabolic diseases, cardiovascular diseases, and OSAS [16]. Further, higher TNF- $\alpha$ concentrations were observed in individuals with OSAS, compared to healthy controls. In 2013, Nadeem et al. [17] showed in their meta-analysis of 15 case-control studies that compared to controls, individuals with OSAS had significantly higher TNF- $\alpha$ concentrations. Similarly, in 2015, Wang et al. [18] also reported in their meta-analysis that compared to healthy controls, individuals with OSAS had significantly higher serum TNF- $\alpha$ concentrations. With the present meta-analysis, we expand upon the previous two meta-analyses in that we focused on (a) both on serum and on plasma TNF- $\alpha$, (b) on samples with adults and children with OSAS, and in that (c) we performed a meta-regression, and (d) we ran sub-group analyses.

\section{Materials and Methods}

The meta-analysis was performed in accordance with the Preferred Reporting Items for Systematic Reviews and Meta-Analyses (PRISMA) guidelines [19].

\subsection{Search Strategy}

One of the authors (M. Sadeghi) systematically searched four databases, namely PubMed/Medline, Scopus, Cochrane Library, and Web of Science, for articles published in English up to 1 February 2020, with no restrictions, and with the following expressions: "sleep apnea" or "OSA" or "obstructive sleep apnea" or "obstructive sleep apnea syndrome" or "OSAS", with "TNF-alpha" or "TNF- $\alpha$ " or "TNF" or "tumor necrosis factor alpha"; and with "blood" or "plasma" or "serum". We also manually inspected the reference lists of the articles (original and review articles) for publications related to our topic.

\subsection{Eligibility Criteria}

Inclusion criteria were as follows: (1) studies evaluating the association between plasma or serum TNF- $\alpha$ levels and OSAS with case-control design without age ( $\geq 18$ years as adults and $<18$ years as children), sex or BMI restrictions; (2) OSAS was defined as AHI $>5$ events/h diagnosed by polysomnography; (3) participants with OSAS and controls had no other systematic diseases such as diabetes, asthma, neurological disorders such as multiple sclerosis, neurodegenerative disorders such as Alzheimer's disease, or oral diseases; (4) studies reporting pretreatment morning serum and/or plasma levels of TNF- $\alpha$ (around 6:00-10:00 a.m.); (5) studies reporting sufficient data to compute the MD and 95\% confidence interval (CI) in participants with OSAS and controls; (6) studies with more than 10 cases included as individuals with OSAS and controls.

Exclusion criteria were: (1) studies with irrelevant or insufficient data or without clinical data; (2) Letter to the editors, review articles, conference papers, meeting abstracts, and book chapters; 
(3) studies without a control group; (4) studies reporting controls with AHI > 5 events/h; (5) studies with overlapped data with other studies; (6) studies without reporting cut-off AHI values for OSAS; (7) studies mixing pediatric and adult participants.

\subsection{Study Selection}

Two authors (M.M.I. and M.E.) read independently the titles and abstracts of the retrieved studies. They then selected the relevant studies, while another author (M.S.) retrieved the full-texts of the articles and excluded several full-texts based on the exclusion criteria mentioned above. If two studies had overlapped data, we selected the study with the most recent publication year.

\subsection{Data Extraction}

Two authors (S.B. and M.S.) independently extracted the data from each study included in the meta-analysis. If there was a disagreement between the two authors, the third author (M.M.I.) helped to find a final decision. The data extracted for the meta-analysis included basic information including the first author, publication year, country of study, ethnicity of subjects in each study, age, BMI, and AHI of both groups, and mean and standard deviation (SD) of TNF- $\alpha$ levels in plasma and serum. Since some studies considered patients with mild OSAS (AHI: 1-5 events/h) as a control group condition, and since we had to use this protocol for other studies, reporting the quality of studies as for usual case-control studies did not seem to be reasonable.

\subsection{Quality Assessment}

One author (M.S) evaluated the quality of the studies included in the meta-analysis using the Newcastle-Ottawa Scale (NOS) with a total score of nine for each study [20].

\subsection{Statistical Analyses}

The data were analyzed by one author. Review Manager 5.3 software (RevMan 5.3, (RevMan 5.3, The Cochrane Collaboration, Oxford, UK) was used to calculate the crude MD and 95\% CI, which evaluated the significance of the pooled MD by Z-test. Heterogeneity across the studies was evaluated using both Cochran Q [21] and I2 metrics with scores ranging from $0 \%$ to $100 \%$ [22]. In addition, when $p$-value $<0.1$ and I2 $>50 \%$ showed a statistically significant heterogeneity, the analysis was performed by the random-effect model to evaluate the pooled ORs and CI values. Otherwise, we used the fixed-effect model. The weight $(\%)$ represents the effect of an individual study on the pooled results obtained. In general, the larger the sample size and the narrower $\mathrm{CI}$ are, the higher is the percentage of weight.

The results of the Begg's and Egger's tests were analyzed by the Comprehensive Meta-Analysis version 2.0 software (CMA 2.0). The Begg's funnel plot shows the standard error (SE) of the log (MD), and the precision of each study is plotted against its log (MD) [23]. In addition, the Egger's test shows the linear regression between the precision of the studies and the standardized effect [24].

Subgroup analyses were performed based on ethnicity, AHI, BMI, and number of participants. The sensitivity analyses, namely the "cumulative analysis" and "one study removed", were applied to estimate the consistency/stability of the results. If the $p$-value (two-tailed) was less than 0.05 , then there was a statistically significant difference. The meta-regression is a quantitative method used in meta-analyses to estimate the impact of moderator variables on study effect size. The trim-and-fill method was used to estimate potentially missing studies due to publication bias in the funnel plot and adjusting the overall effect estimate [25].

Some studies reported the values of TNF- $\alpha$ in standard errors (SE); SEs were transformed into standard deviation (SD) ( $\mathrm{SE}=\mathrm{SD} / \sqrt{ } N ; N=$ number of individuals). Some studies reported median and interquartile values, which were transformed into mean and SD [26]. The serum and plasma TNF- $\alpha$ levels were reported in picograms per milliliter $(\mathrm{pg} / \mathrm{mL})$. Participants with BMI $>30 \mathrm{~kg} / \mathrm{m}^{2}$ were considered obese [27]. 


\section{Results}

\subsection{Search Strategies}

The flow chart (Figure 1) sets out the selection process. The search databases yielded 912 articles; of these, 117 full-texts met eligibility criteria after removing duplicates and irrelevant studies. Next, 62 articles were removed with reasons (two were animal studies, three were meta-analyses, six reported polymorphisms of TNF-alpha, twenty-seven either had no control or control group was selected as $\mathrm{AHI}>5$, five were reviews, two had less than ten cases included in both groups, one reported high sensitivity TNF alpha, four had no sufficient data, one had duplicate data with another study, three showed production of TNF alpha by cells, two did not show cut-off of AHI for OSAS, one was the letter to editor, one mixed adults and pediatric samples, one had controls with recurrent tonsillar infection, one had controls with bronchial asthma, one had controls with diabetes, one had no relevant data). This left 55 studies to be analyzed in the meta-analysis [14,16,28-80].

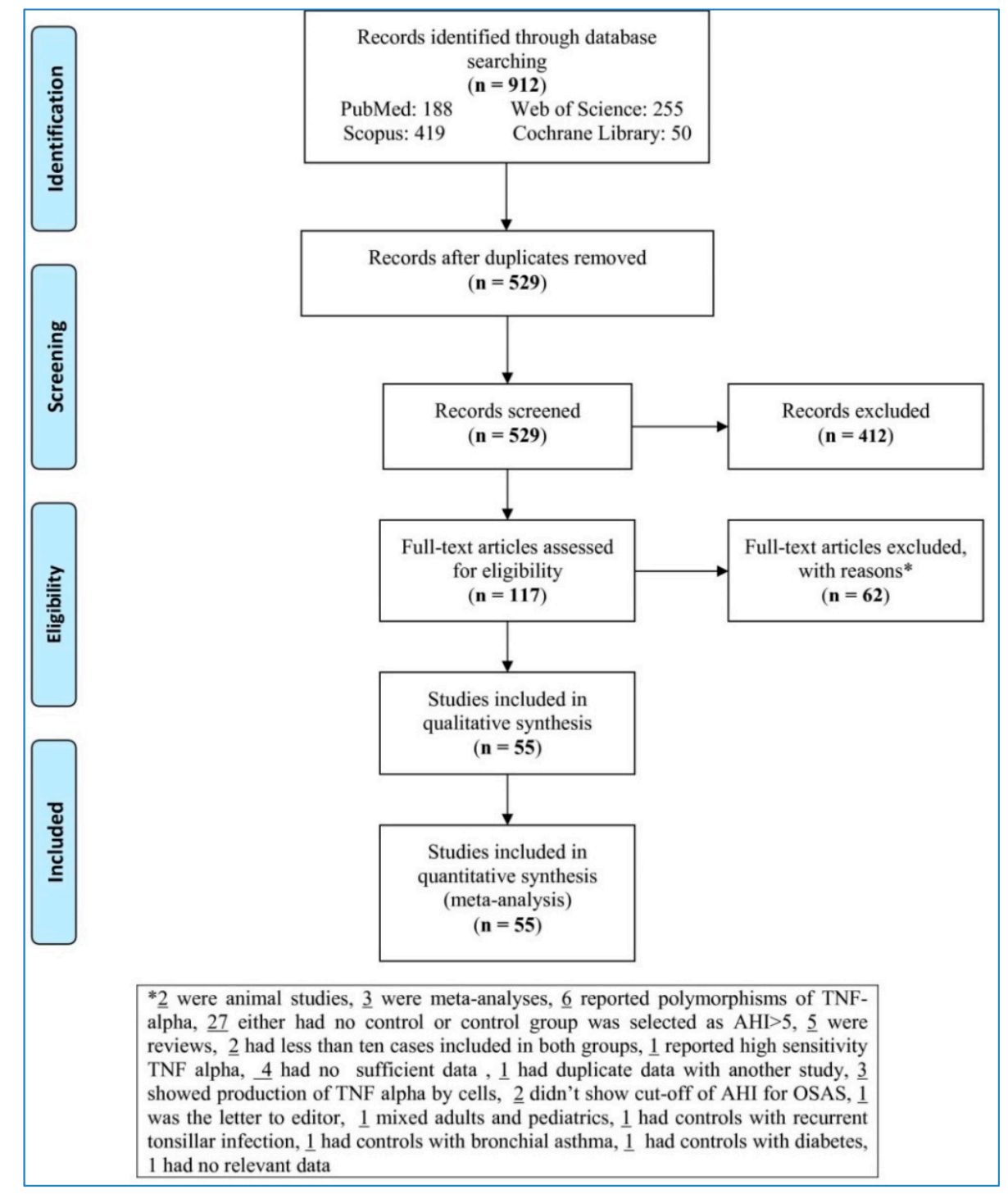

Figure 1. Flowchart of the study selection.

\subsection{Characteristics of Studies}

Table 1 presents the characteristics of the 55 studies included in the meta-analysis. Forty-six studies [16,28-36,38-41,43-52,54,56-65,67-72,75,76,78-80] reported serum or plasma 
TNF- $\alpha$ concentrations in adults, and nine studies $[14,37,42,53,55,66,73,74,77]$ reported serum or plasma TNF- $\alpha$ concentrations in children and adolescents. Among adult participants, eighteen studies were performed with Caucasians [31,34,36,39-41,46-49,59,61,63,65,68,69,75,80], nineteen sampled Asians [16,29,32,33,35,43,45,52,54,58,60,62,64,67,71,72,76,78,79], and nine samples mixed $[28,30,38,44,50,51,56,57,70]$ ethnicities. For studies with adult samples, 29 out of 46 studies reported serum TNF- $\alpha$ concentrations $[16,31-36,38,40,41,45,46,48,50-52,56,60,61,63-65,67,68,70,76,78-80]$ and 17 reported plasma TNF- $\alpha$ concentrations [28-30,39,43,44,47,49,54,57-59,62,69,71,72,75].

\subsection{Overall Analysis}

\subsubsection{Serum Levels of TNF- $\alpha$ in Adults}

Twenty-nine studies compared serum TNF- $\alpha$ concentrations between adults with OSAS and healthy controls (Figure 2); adults with OSAS had significantly higher TNF- $\alpha$ concentrations compared to healthy controls: $10.22 \mathrm{pg} / \mathrm{mL}\left(95 \% \mathrm{CI}=8.86,11.58 ; p<0.00001 ; \mathrm{I}^{2}=100 \%\left(\mathrm{P}_{\mathrm{h}}\right.\right.$ or $\left.\mathrm{P}_{\text {heterogeneity }}<0.00001\right)$ ).

\begin{tabular}{|c|c|c|c|c|c|c|c|c|c|c|c|c|c|}
\hline \multirow[b]{2}{*}{ Study or Subgroup } & \multicolumn{3}{|c|}{ OSAS } & \multicolumn{3}{|c|}{ Control } & \multicolumn{3}{|c|}{ Mean Difference } & \multirow{2}{*}{\multicolumn{4}{|c|}{$\begin{array}{l}\text { Mean Difference } \\
\text { IV, Random, } 95 \% \mathrm{Cl}\end{array}$}} \\
\hline & Mean & SD & Total & Mean & SD & Total & Weight & IV, Random, $95 \% \mathrm{Cl}$ & Year & & & & \\
\hline Ciftci, 2004 & 4.6 & 3.39 & 43 & 3.29 & 2.13 & 22 & $4.9 \%$ & $1.31[-0.04,2.66]$ & 2004 & & & $F$ & \\
\hline Minoguchi, 2004 & 302.72 & 259 & 24 & 73.07 & 46.8 & 27 & $0.0 \%$ & $229.65[124.54,334.76]$ & 2004 & & & & ' \\
\hline Imagawa, 2004 & 26 & 29.07 & 118 & 25 & 26.4 & 47 & $1.5 \%$ & $1.00[-8.19,10.19]$ & 2004 & & & & \\
\hline Tazaki, 2004 & 2.31 & 0.2 & 48 & 1.16 & 0.11 & 18 & $5.2 \%$ & $1.15[1.07,1.23]$ & 2004 & & & - & \\
\hline Ryan, 2005 & 2.6 & 2.54 & 19 & 1.26 & 1.42 & 17 & $4.9 \%$ & $1.34[0.01,2.67]$ & 2005 & & & - & \\
\hline Ryan, 2006 & 5.11 & 2.38 & 66 & 3.21 & 1.47 & 30 & $5.1 \%$ & $1.90[1.12,2.68]$ & 2006 & & & - & \\
\hline Kobayashi, 2006 & 1.11 & 0.46 & 35 & 0.62 & 0.44 & 16 & $5.2 \%$ & $0.49[0.23,0.75]$ & 2006 & & & & \\
\hline de la Peña Bravo, 2007 & 0.84 & 0.47 & 50 & 0.42 & 0.11 & 20 & $5.2 \%$ & $0.42[0.28,0.56]$ & 2007 & & & & \\
\hline Kanbay, 2008 & 117.4 & 148.2 & 106 & 45.77 & 24.17 & 32 & $0.2 \%$ & $71.63[42.20,101.06]$ & 2008 & & & & ' \\
\hline Constantinidis, 2008 & 115.62 & 93.04 & 24 & 61.94 & 42.59 & 27 & $0.1 \%$ & $53.68[13.14,94.22]$ & 2008 & & & & $\rightarrow$ \\
\hline Li, 2009 & 119.8 & 11.33 & 68 & 87.3 & 6.1 & 22 & $3.7 \%$ & $32.50[28.79,36.21]$ & 2009 & & & & ' \\
\hline Thomopoulos, 2009 & 2.13 & 1.86 & 62 & 1.26 & 1.7 & 70 & $5.1 \%$ & $0.87[0.26,1.48]$ & 2009 & & & - & \\
\hline Steiropoulos, 2010 & 6.72 & 3.72 & 38 & 3.94 & 1.34 & 23 & $4.9 \%$ & $2.78[1.48,4.08]$ & 2010 & & & $\rightarrow$ & \\
\hline Fornadi, 2012 & 2.2 & 0.96 & 25 & 1.9 & 0.96 & 75 & $5.1 \%$ & $0.30[-0.13,0.73]$ & 2012 & & & & \\
\hline Qian, 2012 & 1.23 & 0.28 & 70 & 1.14 & 0.4 & 40 & $5.2 \%$ & $0.09[-0.05,0.23]$ & 2012 & & & & \\
\hline Medeiros, 2012 & 1.71 & 5.69 & 50 & 0.32 & 0.77 & 15 & $4.8 \%$ & $1.39[-0.23,3.01]$ & 2012 & & & - & \\
\hline Hargens, 2013 & 950 & 242.48 & 12 & 860 & 287.22 & 33 & $0.0 \%$ & $90.00[-78.60,258.60]$ & 2013 & & & & \\
\hline Sun, 2014 & 18.05 & 7.36 & 121 & 10.3 & 5.23 & 18 & $4.3 \%$ & $7.75[5.00,10.50]$ & 2014 & & & & \\
\hline Unuvar Dogan, 2014 & 0.128 & 0.15 & 33 & 0.108 & 0.027 & 24 & $5.2 \%$ & $0.02[-0.03,0.07]$ & 2014 & & & & \\
\hline Thunström, 2015 & 5 & 2.66 & 234 & 4.2 & 2.22 & 95 & $5.1 \%$ & $0.80[0.24,1.36]$ & 2015 & & & - & \\
\hline Jiang, 2015 & 765.77 & 64.04 & 135 & 232.24 & 31.5 & 94 & $1.0 \%$ & $533.53[520.99,546.07]$ & 2015 & & & & ' \\
\hline De, 2015 & 122.2 & 12 & 26 & 80.2 & 18.3 & 24 & $1.7 \%$ & $42.00[33.35,50.65]$ & 2015 & & & & ' \\
\hline Lin, 2016 & 24 & 7.7 & 35 & 14 & 5 & 20 & $3.9 \%$ & $10.00[6.64,13.36]$ & 2016 & & & & \\
\hline Nizam, 2016 & 82.99 & 51.36 & 38 & 82.33 & 28.44 & 13 & $0.3 \%$ & $0.66[-21.83,23.15]$ & 2016 & 4 & & & $\rightarrow$ \\
\hline Hirotsu, 2017 & 10.92 & 6.19 & 339 & 9.83 & 6.02 & 682 & $5.1 \%$ & $1.09[0.29,1.89]$ & 2017 & & & - & \\
\hline Kong, 2018 & 327.34 & 46.81 & 50 & 307.95 & 27.15 & 40 & $0.7 \%$ & $19.39[3.93,34.85]$ & 2018 & & & & $\longrightarrow$ \\
\hline Ming, 2019 & 31.2 & 5.3 & 684 & 12.1 & 1.1 & 192 & $5.1 \%$ & $19.10[18.67,19.53]$ & 2019 & & & & - \\
\hline Tang, 2019 & 336.34 & 40.16 & 120 & 321.9 & 27.18 & 127 & $1.7 \%$ & $14.44[5.84,23.04]$ & 2019 & & & & \\
\hline Galati, 2020 & 4.85 & 5.26 & 45 & 1.97 & 1.43 & 30 & $4.8 \%$ & $2.88[1.26,4.50]$ & 2020 & & & $\rightarrow$ & \\
\hline Total $(95 \% \mathrm{Cl})$ & & & 2718 & & & 1893 & $100.0 \%$ & $10.22[8.86,11.58]$ & & & & & \\
\hline \multicolumn{10}{|c|}{$\begin{array}{l}\text { Heterogeneity: } \text { Tau }^{2}=9.34 ; C \mathrm{Ci}^{2}=15415.44, \mathrm{df}=28(\mathrm{P}<0.00001) ; \mathrm{l}^{\mathbf{2}}=100 \% \\
\text { Test for overall effect: } Z=14.72(P<0.00001)\end{array}$} & -20 & $\begin{array}{cc}-10 & 0 \\
\text { Favours [OSAS] }\end{array}$ & $\begin{array}{c}10 \\
\text { Favours [control] }\end{array}$ & 20 \\
\hline
\end{tabular}

Figure 2. Forest plot of serum tumor necrosis factor alpha levels in adult participants with obstructive sleep apnea syndrome patients compared to controls. 
Table 1. Characteristics of studies included in the meta-analysis $(n=55)$.

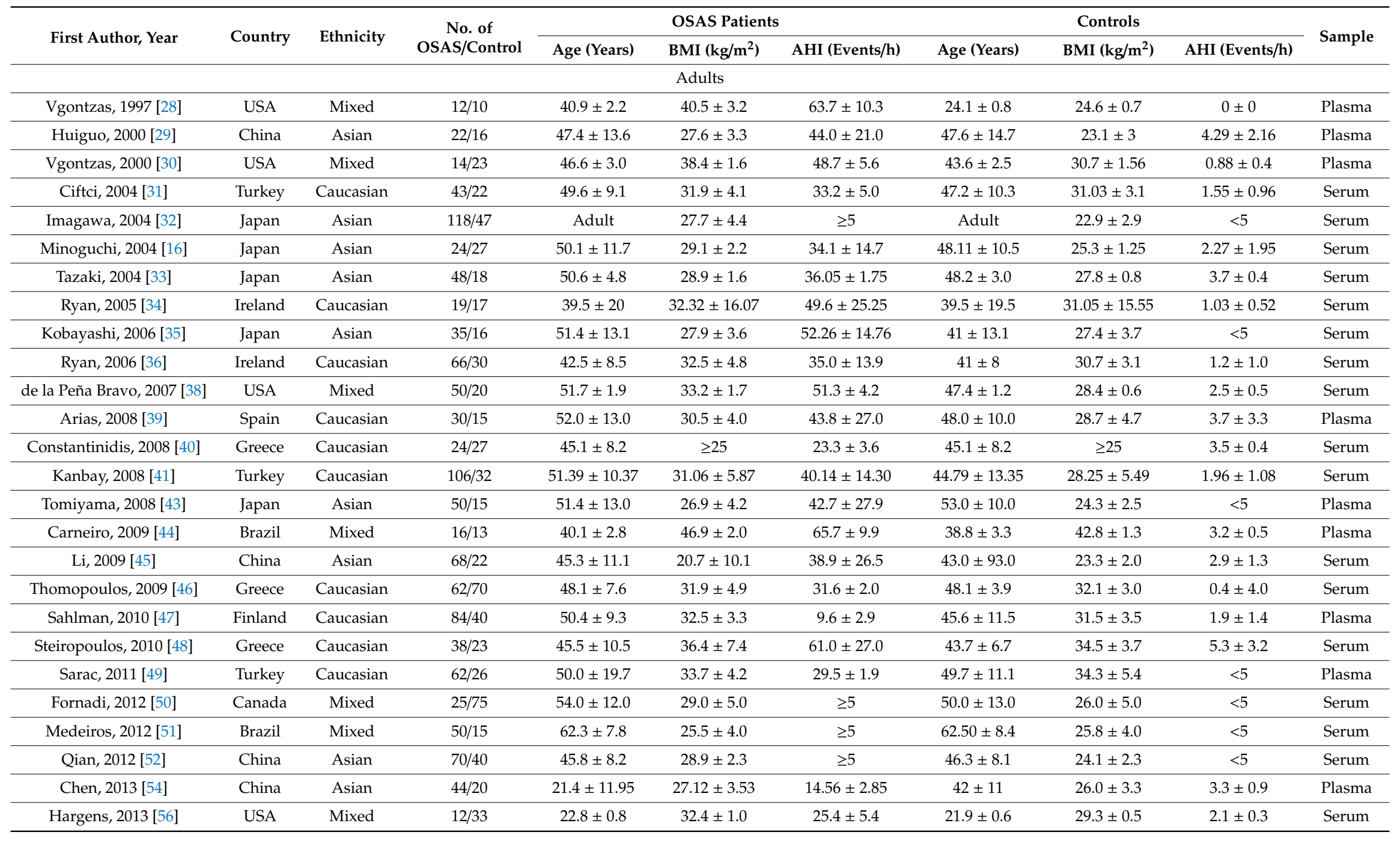


Table 1. Cont

\begin{tabular}{|c|c|c|c|c|c|c|c|c|c|c|}
\hline \multirow{2}{*}{ First Author, Year } & \multirow[b]{2}{*}{ Country } & \multirow{2}{*}{ Ethnicity } & \multirow{2}{*}{$\begin{array}{c}\text { No. of } \\
\text { OSAS/Control }\end{array}$} & \multicolumn{3}{|c|}{ OSAS Patients } & \multicolumn{3}{|c|}{ Controls } & \multirow{2}{*}{ Sample } \\
\hline & & & & Age (Years) & BMI $\left(\mathrm{kg} / \mathrm{m}^{2}\right)$ & AHI (Events/h) & Age (Years) & BMI $\left(\mathrm{kg} / \mathrm{m}^{2}\right)$ & AHI (Events/h) & \\
\hline Matos, 2013 [57] & Brazil & Mixed & $119 / 187$ & 51.2 & 29.7 & $\geq 5$ & 40.7 & 24.5 & $<5$ & Plasma \\
\hline Yang, 2013 [58] & China & Asian & $50 / 25$ & $53.5 \pm 6.9$ & $27.4 \pm 2.9$ & $24.5 \pm 15.9$ & $53.0 \pm 7.0$ & $26.27 \pm 1.9$ & $3.0 \pm 1.0$ & Plasma \\
\hline Ciccone, 2014 [59] & Italy & Caucasian & $80 / 40$ & $52.8 \pm 10.6$ & $28.6 \pm 3.0$ & $33.9 \pm 21$ & $52.3 \pm 10.5$ & $28.2 \pm 2.7$ & $2.1 \pm 1.1$ & Plasma \\
\hline Sun, 2014 [60] & China & Asian & $121 / 18$ & $43.3 \pm 11.6$ & $27.1 \pm 3.1$ & $40.8 \pm 10.9$ & $43.9 \pm 13.4$ & $25.7 \pm 3.8$ & $2.1 \pm 1.8$ & Serum \\
\hline Unuvar Dogan, 2014 [61] & Turkey & Caucasian & $33 / 24$ & $45.3 \pm 8.5$ & $31.0 \pm 1.7$ & $47.2 \pm 23.2$ & $40.5 \pm 9.5$ & $30.7 \pm 1.5$ & $3.6 \pm 1.8$ & Serum \\
\hline Chen, 2015 [62] & China & Asian & $93 / 28$ & $42.28 \pm 8.55$ & $28.84 \pm 3.82$ & $27 \pm 4.06$ & $43.7 \pm 9.8$ & $26.4 \pm 2.5$ & $2.6 \pm 1.2$ & Plasma \\
\hline Jiang, 2015 [64] & China & Asian & $135 / 94$ & $48.7 \pm 12.1$ & $27.48 \pm 2.56$ & $24.57 \pm 15.9$ & $47.2 \pm 13.5$ & $27.52 \pm 2.58$ & $1.60 \pm 1.61$ & Serum \\
\hline Thunström, 2015 [65] & Sweden & Caucasian & $234 / 95$ & $65.3 \pm 7.1$ & $26.8 \pm 2.1$ & $28.9 \pm 13.7$ & $61.4 \pm 9.5$ & $25.2 \pm 2.5$ & $3.1 \pm 1.3$ & Serum \\
\hline Lin, 2016 [67] & Taiwan & Asian & $35 / 20$ & $46 \pm 7$ & $29.2 \pm 1.9$ & $59.3 \pm 23.2$ & $43 \pm 8$ & $28.2 \pm 1.6$ & $3.6 \pm 0.8$ & Serum \\
\hline Nizam, 2016 [68] & Turkey & Caucasian & $39 / 13$ & $47.3 \pm 10.4$ & $33.2 \pm 56.4$ & $45.6 \pm 20.7$ & $43.23 \pm 9.08$ & $31.71 \pm 4.56$ & $2.64 \pm 1.82$ & Serum \\
\hline Vicente, 2016 [69] & Spain & Caucasian & $89 / 26$ & $45.33 \pm 14.81$ & $30.03 \pm 5.04$ & $28 \pm 23.70$ & $45 \pm 11.11$ & $28.7 \pm 4.37$ & $1.9 \pm 2.7$ & Plasma \\
\hline Hirotsu, 2017 [70] & Brazil & Mixed & $339 / 682$ & $50.8 \pm 13.2$ & $29.6 \pm 5.8$ & $19.3 \pm 9.44$ & $38.2 \pm 12.7$ & $25.4 \pm 3.8$ & $2.5 \pm 10.4$ & Serum \\
\hline Jiang, 2017 [71] & China & Asian & $120 / 40$ & $24.82 \pm 10.7$ & $28.5 \pm 5.13$ & $46.6 \pm 4.56$ & $46.5 \pm 12.3$ & $27.5 \pm 6.2$ & $2.13 \pm 1.26$ & Plasma \\
\hline Bozic, 2018 [75] & Croatia & Caucasian & $50 / 25$ & $53.0 \pm 11.9$ & $28.9 \pm 2.7$ & $35.0 \pm 11.0$ & $52.5 \pm 10.2$ & $27.8 \pm 2.2$ & $<5$ & Plasma \\
\hline Kong, 2018 [76] & China & Asian & $50 / 40$ & $54.34 \pm 14.38$ & $26.86 \pm 3.12$ & $37.34 \pm 19.02$ & $50.42 \pm 8.35$ & $22.26 \pm 3.54$ & $3.31 \pm 1.09$ & Serum \\
\hline Ming, 2019 [78] & China & Asian & $684 / 192$ & $51.34 \pm 5.16$ & $\leq 30$ & $31.15 \pm 9.12$ & $52.18 \pm 4.51$ & $\leq 30$ & $4.34 \pm 2.01$ & Serum \\
\hline Tang, 2019 [79] & China & Asian & $120 / 127$ & $48.88 \pm 9.76$ & $26.86 \pm 3.12$ & $39.00 \pm 18.38$ & $47.37 \pm 9.12$ & $22.46 \pm 3.29$ & $3.31 \pm 1.09$ & Serum \\
\hline Galati, 2020 [80] & Italy & Caucasian & $45 / 30$ & $53.9 \pm 11.6$ & $28 \pm 2.2$ & $\geq 5$ & $55 \pm 5.8$ & $26.3 \pm 1.8$ & $<5$ & Serum \\
\hline \multicolumn{11}{|c|}{ Pediatrics } \\
\hline Tam, 2006 [37] & Australia & Mixed & $44 / 69$ & $7.3 \pm 3.7$ & $19.4 \pm 5.5$ & $5.3 \pm 6.5$ & $7.6 \pm 4.0$ & $17.9 \pm 3.9$ & $0 \pm 0$ & Serum \\
\hline $\mathrm{Li}, 2008$ [42] & China & Asian & $47 / 95$ & $11.1 \pm 1.27$ & NR & $14.1 \pm 8.0$ & $10.7 \pm 1.3$ & NR & $0.7 \pm 0.6$ & Serum \\
\hline Alexopoulos, 2013 [53] & Greece & Caucasian & $24 / 44$ & $5.7 \pm 2$ & $<25$ & $11.5 \pm 5.1$ & $6.4 \pm 2.3$ & $<25$ & $1.3 \pm 0.65$ & Plasma \\
\hline Chu, 2013 [55] & China & Asian & $55 / 35$ & Child & NR & $\geq 5$ & Child & NR & $<5$ & Plasma \\
\hline Gaines, 2016 [66] & USA & Mixed & $44 / 348$ & $18.41 \pm 2.2$ & NR & $12.08 \pm 4.64$ & $18.4 \pm 2.2$ & NR & $1.65 \pm 4.81$ & Plasma \\
\hline Huang, 2016 [14] & Taiwan & Asian & $47 / 32$ & $7.84 \pm 0.56$ & $16.95 \pm 0.47$ & $9.13 \pm 1.67$ & $7.02 \pm 0.65$ & $6.55 \pm 0.58$ & $0.41 \pm 0.07$ & Plasma \\
\hline Smith, 2017 [73] & USA & Mixed & $33 / 98$ & $9.0 \pm 2.7$ & $23.4 \pm 13.5$ & $15.2 \pm 11.7$ & $19.66 \pm 4.44$ & $9.68 \pm 2.5$ & $1.03 \pm 0.46$ & Plasma \\
\hline Zhang, 2017 [74] & China & Asian & $50 / 52$ & 6.6 & NR & $\geq 5$ & 6.4 & NR & $<5$ & Serum \\
\hline Rogers, 2018 [77] & USA & Mixed & $20 / 7$ & $7.9 \pm 2.2$ & $<25$ & $13.1 \pm 9.8$ & $7.9 \pm 2.2$ & $<25$ & $0.8 \pm 0.3$ & Serum \\
\hline
\end{tabular}

NR, Not reported; OSAS, Obstructive sleep apnea syndrome; AHI, Apnea-hypopnea index; BMI, Body mass index. 


\subsubsection{Plasma Levels of TNF- $\alpha$ in Adults}

Seventeen studies compared plasma TNF- $\alpha$ concentrations between adults with OSAS and healthy controls (Figure 3) and found significantly higher TNF- $\alpha$ concentrations in those with OSAS: $5.90 \mathrm{pg} / \mathrm{mL}$ $\left(95 \% \mathrm{CI}=4.00,7.80 ; p<0.00001 ; \mathrm{I}^{2}=99 \%\left(\mathrm{P}_{\mathrm{h}}<0.00001\right)\right)$.

\begin{tabular}{|c|c|c|c|c|c|c|c|c|c|c|c|c|c|}
\hline \multirow[b]{2}{*}{ Study or Subgroup } & \multicolumn{3}{|c|}{ OSAS } & \multicolumn{3}{|c|}{ Control } & \multicolumn{3}{|c|}{ Mean Difference } & \multirow{2}{*}{\multicolumn{4}{|c|}{$\begin{array}{c}\text { Mean Difference } \\
\text { IV, Random, } 95 \% \mathrm{Cl}\end{array}$}} \\
\hline & Mean & SD & Total & Mean & SD & Total & Weight & IV, Random, $95 \% \mathrm{Cl}$ & Year & & & & \\
\hline Vgontzas, 1997 & 2.51 & 0.45 & 12 & 1.17 & 0.32 & 10 & $7.1 \%$ & $1.34[1.02,1.66]$ & 1997 & & & $\rightarrow$ & \\
\hline Huiguo, 2000 & 299.09 & 43.57 & 22 & 101.88 & 21.27 & 16 & $0.7 \%$ & $197.21[176.23,218.19]$ & 2000 & & & & - \\
\hline Vgontzas, 2000 & 3.36 & 0.71 & 14 & 3.04 & 0.61 & 23 & $0.0 \%$ & $0.32[-0.13,0.77]$ & 2000 & & & & \\
\hline Tomiyama, 2008 & 1.99 & 0.52 & 50 & 1.07 & 0.5 & 15 & $7.1 \%$ & $0.92[0.63,1.21]$ & 2008 & & & - & \\
\hline Arias, 2008 & 18.5 & 13.4 & 30 & 11.4 & 12.2 & 15 & $3.2 \%$ & $7.10[-0.72,14.92]$ & 2008 & & & & \\
\hline Carneiro, 2009 & 10.7 & 1.66 & 16 & 7.5 & 0.44 & 13 & $7.0 \%$ & $3.20[2.35,4.05]$ & 2009 & & & - & \\
\hline Sahıman, 2010 & 1.54 & 1.75 & 84 & 1.17 & 1.58 & 40 & $7.1 \%$ & $0.37[-0.25,0.99]$ & 2010 & & & - & \\
\hline Sarac, 2011 & 10.1 & 2.5 & 62 & 9.1 & 1.8 & 26 & $7.0 \%$ & $1.00[0.07,1.93]$ & 2011 & & & - & \\
\hline Chen, 2013 & 3.27 & 3.89 & 44 & 1.2 & 0.89 & 20 & $6.9 \%$ & $2.07[0.86,3.28]$ & 2013 & & & $\longrightarrow$ & \\
\hline Yang, 2013 & 14.71 & 9.94 & 50 & 14.53 & 6.34 & 50 & $5.9 \%$ & $0.18[-3.09,3.45]$ & 2013 & & & & \\
\hline Matos, 2013 & 11.58 & 7.09 & 119 & 12.14 & 9.84 & 187 & $6.6 \%$ & $-0.56[-2.46,1.34]$ & 2013 & & & - & \\
\hline Ciccone, 2014 & 23.69 & 3.68 & 80 & 12.53 & 3.48 & 40 & $6.9 \%$ & $11.16[9.81,12.51]$ & 2014 & & & & $\longrightarrow$ \\
\hline Chen, 2015 & 26.45 & 3.12 & 93 & 12.53 & 3.48 & 28 & $6.8 \%$ & $13.92[12.48,15.36]$ & 2015 & & & & ' \\
\hline Vicente, 2016 & 4.6 & 0.75 & 89 & 4.45 & 0.72 & 26 & $7.1 \%$ & $0.15[-0.17,0.47]$ & 2016 & & & & \\
\hline $\operatorname{Jin}, 2017$ & 37.67 & 0.21 & 100 & 29.15 & 1.74 & 50 & $7.1 \%$ & $8.52[8.04,9.00]$ & 2017 & & & - & \\
\hline Jiang, 2017 & 27.51 & 7.25 & 120 & 12.66 & 6.67 & 40 & $6.4 \%$ & $14.85[12.41,17.29]$ & 2017 & & & & ' \\
\hline Bozic, 2018 & 7.23 & 1.93 & 50 & 2.35 & 1.25 & 25 & $7.0 \%$ & $4.88[4.15,5.61]$ & 2018 & & & $\rightarrow$ & \\
\hline Total $(95 \% \mathrm{Cl})$ & & & 1021 & & & 601 & $100.0 \%$ & $5.90[4.00,7.80]$ & & & & & \\
\hline \multicolumn{10}{|c|}{$\begin{array}{l}\text { Heterogeneity: } \text { Tau }^{2}=13.21 ; \mathrm{Chi}^{2}=1885.00, \mathrm{df}=15(\mathrm{P}<0.00001) ; \mathrm{I}^{2}=99 \% \\
\text { Test for overall effect: } Z=6.09(P<0.00001)\end{array}$} & -10 & $\begin{array}{cc}-5 & 1 \\
\text { Favours [OSAS] }\end{array}$ & \begin{tabular}{|c|}
5 \\
Favours [control]
\end{tabular} & 10 \\
\hline
\end{tabular}

Figure 3. Forest plot of plasma tumor necrosis factor alpha levels in adult participants with obstructive sleep apnea syndrome patients compared to controls.

\subsubsection{Serum TNF- $\alpha$ Levels in Children}

Four studies compared serum TNF- $\alpha$ concentrations between children with OSAS and without OSAS (Figure 4 ) and found significantly higher TNF- $\alpha$ concentrations in those with OSAS: $0.21 \mathrm{pg} / \mathrm{mL}$ $\left(95 \% \mathrm{CI}=0.05,0.37 ; p=0.01 ; \mathrm{I}^{2}=77 \%\left[\mathrm{P}_{\mathrm{h}}=0.005\right]\right.$.

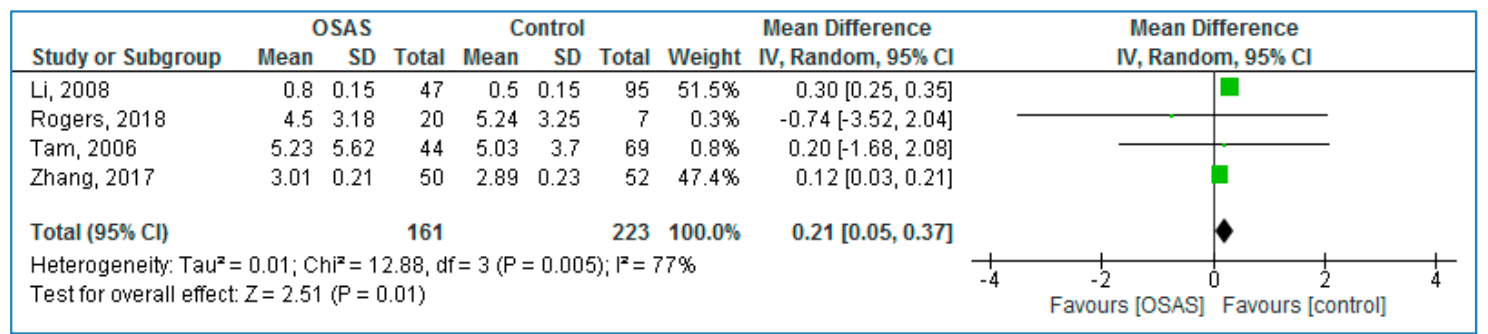

Figure 4. Forest plot of serum tumor necrosis factor alpha levels in pediatric participants with obstructive sleep apnea syndrome patients compared to controls.

\subsubsection{Plasma TNF- $\alpha$ Levels in Children}

Five studies compared serum TNF- $\alpha$ concentrations between children with OSAS and without OSAS (Figure 5) and found no statistically significant MDs: $0.15 \mathrm{pg} / \mathrm{mL}(95 \% \mathrm{CI}=-0.16,0.45 ; p=0.35$; $\left.\mathrm{I}^{2}=61 \%\left[\mathrm{P}_{\mathrm{h}}=0.04\right]\right)$. 


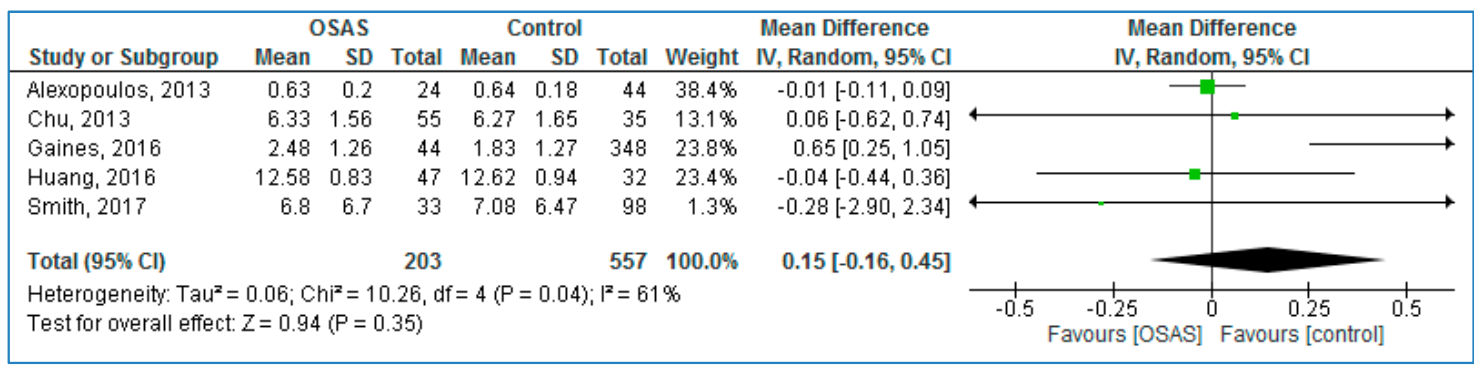

Figure 5. Forest plot of plasma tumor necrosis factor alpha levels in pediatric participants with obstructive sleep apnea syndrome patients compared to controls.

\subsection{Overall Subgroup Analysis of Serum and Plasma TNF- $\alpha$ Levels}

\subsubsection{Ethnicity}

Subgroup analysis of serum TNF- $\alpha$ concentrations in adult samples are reported in Table 2. The pooled analysis showed that for those with OSAS, serum TNF- $\alpha$ concentrations in Asians $(\mathrm{MD}=37.11 \mathrm{pg} / \mathrm{mL}(95 \% \mathrm{CI}=33.27,40.95 ; p<0.00001)$, in Caucasians $(\mathrm{MD}=2.20 \mathrm{pg} / \mathrm{mL}$; $95 \% \mathrm{CI}=1.06,3.34 ; p=0.0002)$, and in mixed ethnicities $(\mathrm{MD}=0.43 ; 95 \% \mathrm{CI}=0.30,0.56 ; p<0.00001)$ were significantly higher, compared to healthy controls. Serum TNF- $\alpha$ concentrations in Asians were 16.9 and 86.3 times higher than serum TNF- $\alpha$ concentrations in Caucasian and mixed ethnicities with OSAS, and always compared to controls.

For plasma TNF- $\alpha$ concentrations, for those adults with OSAS, plasma TNF- $\alpha$ concentrations in Asians $(\mathrm{MD}=14.92 \mathrm{pg} / \mathrm{mL} ; 95 \% \mathrm{CI}=9.86,19.98 ; p<0.00001)$, in Caucasians $(\mathrm{MD}=3.72(95 \% \mathrm{CI}=1.04,6.40$; $p=0.007)$ ), and in mixed ethnicities ( $\mathrm{MD}=1.22 ; 95 \% \mathrm{CI}=0.10,2.34 ; p=0.03$ ) were significantly higher, compared to healthy controls. Next, in Asians, plasma TNF- $\alpha$ concentrations were 4 and 12.2 times higher than in Caucasian and mixed ethnicities with OSAS, and always compared to controls.

\subsubsection{Mean BMI of Individuals with OSAS}

For serum TNF- $\alpha$ concentrations, and compared to healthy controls, adult participants with OSAS and a BMI $>30 \mathrm{~km} / \mathrm{m}^{2}$ showed a pooled MD of 1.27 (95\% CI: 0.67, 1.86; $\left.p<0.0001\right)$. For adult participants with OSAS and a BMI $\leq 30 \mathrm{~km} / \mathrm{m}^{2}$, the pooled MD was $23.07 \mathrm{pg} / \mathrm{mL}$ (95\% CI: 20.18, 25.96; $p<0.00001$ ). Thus, results showed that serum TNF- $\alpha$ concentrations were 18.2 times higher participants with OSAS and a BMI $>30 \mathrm{~kg} / \mathrm{m}^{2}$, when compared to those participants with a mean $\mathrm{BMI} \leq 30 \mathrm{~kg} / \mathrm{m}^{2}$.

For plasma TNF- $\alpha$ concentrations, and compared to healthy controls, adult participants with OSAS and a BMI $>30 \mathrm{~km} / \mathrm{m}^{2}$ showed a pooled MD of $1.06 \mathrm{pg} / \mathrm{mL}(95 \%$ CI: $0.34,1.78 ; p=0.004)$. For adult participants with OSAS and a BMI $\leq 30 \mathrm{~km} / \mathrm{m}^{2}$, the pooled MD was $10.82 \mathrm{pg} / \mathrm{mL}(95 \%$ CI: $7.14,14.49 ; p<0.00001)$. Thus, results showed that plasma TNF- $\alpha$ concentrations were 10.2 times higher in adults with OSAS and a BMI $>30 \mathrm{~kg} / \mathrm{m}^{2}$ than plasma TNF- $\alpha$ concentrations of adults with OSAS and a BMI $\leq 30 \mathrm{~kg} / \mathrm{m}^{2}$ and always compared to healthy controls.

\subsubsection{Mean BMI of Controls}

For serum TNF- $\alpha$ levels, compared to controls, individuals with OSAS and with a BMI $>30 \mathrm{~kg} / \mathrm{m}^{2}$ showed a pooled MD of $2.28 \mathrm{pg} / \mathrm{mL}$ (95\% CI: 0.86, 3.70; $p=0.002)$; while compared to controls, individuals with OSAS and with a BMI $\leq 30 \mathrm{~kg} / \mathrm{m}^{2}$ showed a pooled MD of $18.64 \mathrm{pg} / \mathrm{mL}(95 \% \mathrm{CI}$ : $16.33,20.95 ; p<0.00001)$. Thus, serum TNF- $\alpha$ levels were 8.2 times higher in studies with participants with OSAS and a BMI $>30 \mathrm{~kg} / \mathrm{m}^{2}$ than serum TNF- $\alpha$ levels with participants with OSAS and a $\mathrm{BMI} \leq 30 \mathrm{~kg} / \mathrm{m}^{2}$.

For plasma TNF- $\alpha$ levels, compared to controls, the pooled MD was $7.32 \mathrm{pg} / \mathrm{mL}$ (95\% CI: 5.02 , 9.62; $p<0.00001$ ) for participants with OSAS and a BMI $>30 \mathrm{~kg} / \mathrm{m}^{2}$; for participants with OSAS and a 
$\mathrm{BMI} \leq 30 \mathrm{~kg} / \mathrm{m}^{2}$, the pooled MD was not statistically significant (MD = $1.19 \mathrm{pg} / \mathrm{mL} ; 95 \% \mathrm{CI}: 0.00,2.38$; $p=0.05)$.

Table 2. Subgroup analysis on serum and plasma levels of tumor necrosis factor alpha in adult participants.

\begin{tabular}{|c|c|c|c|}
\hline $\begin{array}{l}\text { Subgroup Analysis of } \\
\text { Serum Level }(n)\end{array}$ & $\begin{array}{c}\text { MD }(95 \% C I), p \text {-Value, } \\
I^{2}(\%), P_{h}\end{array}$ & $\begin{array}{l}\text { Subgroup Analysis of } \\
\text { Plasma Level }(n)\end{array}$ & $\begin{array}{c}\text { MD }(95 \% C I), p \text {-Value, } \\
I^{2}(\%), P_{h}\end{array}$ \\
\hline Overall (29) & $\begin{array}{c}10.22(8.86,11.58) \\
<0.00001 ; 100,<0.00001\end{array}$ & Overall (17) & $\begin{array}{c}5.41(3.66,7.15) \\
<0.00001,99,<0.00001\end{array}$ \\
\hline Ethnicity & - & Ethnicity & - \\
\hline Caucasian (12) & $\begin{array}{c}2.20(1.06,3.34), 0.0002 \\
94,<0.00001\end{array}$ & Caucasian (6) & $\begin{array}{c}3.72(1.04,6.40), 0.007 \\
99,<0.00001\end{array}$ \\
\hline Asian (12) & $\begin{array}{c}37.11(33.27,40.95) \\
<0.00001,100,<0.00001\end{array}$ & Asian (7) & $\begin{array}{c}14.92(9.86,19.98) \\
<0.00001,100,<0.00001\end{array}$ \\
\hline Mixed (5) & $\begin{array}{c}0.43(0.30,0.56) \\
<0.00001,26,0.25\end{array}$ & Mixed (4) & $\begin{array}{c}1.22(0.10,2.34), 0.03 \\
93,<0.00001\end{array}$ \\
\hline $\begin{array}{l}\text { Mean BMI of OSAS } \\
\text { patients, } \mathrm{kg} / \mathrm{m}^{2}\end{array}$ & - & $\begin{array}{l}\text { Mean BMI of OSAS } \\
\text { patients, } \mathrm{kg} / \mathrm{m}^{2}\end{array}$ & - \\
\hline$>30(11)$ & $\begin{array}{c}1.27(0.67,1.86) \\
<0.0001,95,<0.000001\end{array}$ & $>30(7)$ & $\begin{array}{c}1.06(0.34,1.78), 0.004 \\
91,<0.00001\end{array}$ \\
\hline$\leq 30(17)$ & $\begin{array}{c}23.07(20.18,25.96) \\
<0.00001,100,<0.00001\end{array}$ & $\leq 30(10)$ & $\begin{array}{c}10.82(7.14,14.49) \\
<0.00001,99,<0.00001\end{array}$ \\
\hline $\begin{array}{l}\text { Mean BMI of } \\
\text { controls, } \mathrm{kg} / \mathrm{m}^{2}\end{array}$ & - & $\begin{array}{c}\text { Mean BMI of } \\
\text { controls, } \mathrm{kg} / \mathrm{m}^{2}\end{array}$ & - \\
\hline$>30(8)$ & $\begin{array}{c}2.28(0.86,3.70), 0.002 \\
95,<0.00001\end{array}$ & $>30(4)$ & $\begin{array}{c}1.19(0.00,2.38), 0.05 \\
92,<0.00001\end{array}$ \\
\hline$\leq 30(20)$ & $\begin{array}{c}18.64(16.33,20.95) \\
<0.00001,100,<0.00001\end{array}$ & $\leq 30(13)$ & $\begin{array}{c}7.32(5.02,9.62) \\
<0.00001,99,<0.00001\end{array}$ \\
\hline $\begin{array}{l}\text { Total number of } \\
\text { participants }\end{array}$ & - & $\begin{array}{l}\text { Total number of } \\
\text { participants }\end{array}$ & - \\
\hline$>100(10)$ & $\begin{array}{c}55.47(47.21,63.72) \\
<0.00001,100,<0.00001\end{array}$ & $>100$ (7) & $\begin{array}{c}6.91(2.20,11.63), 0.004 \\
100,<0.00001\end{array}$ \\
\hline$\leq 100(19)$ & $\begin{array}{c}2.15(1.57,2.72) \\
<0.00001,98,<0.00001\end{array}$ & $\leq 100$ (10) & $\begin{array}{c}2.87(1.37,4.37), 0.0002 \\
98,<0.00001\end{array}$ \\
\hline $\begin{array}{l}\text { Mean AHI of OSAS } \\
\text { patients, events/h }\end{array}$ & - & $\begin{array}{l}\text { Mean AHI of OSAS } \\
\text { patients, events/h }\end{array}$ & - \\
\hline$>30(18)$ & $\begin{array}{c}5.72(4.32,7.12) \\
<0.00001,100,<0.00001\end{array}$ & $>30$ (10) & $\begin{array}{c}8.15(5.59,10.71) \\
<0.00001,99,<0.00001\end{array}$ \\
\hline$\leq 30(6)$ & $\begin{array}{l}127.01(100.56,153.47) \\
<0.00001,100,<0.00001\end{array}$ & $\leq 30(6)$ & $\begin{array}{c}2.97(0.21,5.73), 0.03 \\
99,<0.00001\end{array}$ \\
\hline
\end{tabular}

BMI, Body mass index; CI, Confidence interval; OSAS, Obstructive sleep apnea syndrome; MD, Mean difference; $P_{h}$, $P_{\text {heterogeneity. }}$ Bold numbers show statistically significant value $(p$-value $<0.05)$.

\subsubsection{Total Number of Participants}

For serum TNF- $\alpha$ levels, the pooled MD was 55.47 pg/mL (95\% CI: 47.21, 63.72; $p<0.00001$ ) for studies with more than 100 cases, and $2.15 \mathrm{pg} / \mathrm{mL}$ (95\% CI: 1.57, 2.72; $p<0.00001)$ for studies with less than 100 cases. Thus, serum TNF- $\alpha$ levels were 25.8 times higher in the studies with more 100 cases, compared to studies with less than 100 cases.

For plasma TNF- $\alpha$ levels, the pooled MD was $6.91 \mathrm{pg} / \mathrm{mL}$ (95\%CI: 2.20, 11.63; $p=0.004$ ) for studies with more than 100 cases, while the pooled MD was $2.87 \mathrm{pg} / \mathrm{mL}$ (95\%CI: 1.37, 4.37; $p=0.0002$ ) for 
studies with less than 100 cases. Thus, plasma TNF- $\alpha$ levels were 2.4 times higher in the studies with more than 100 cases, compared to studies with less than 100 cases.

\subsubsection{Mean AHI of Individuals with OSAS}

For serum TNF- $\alpha$ levels, in individuals with OSAS and a AHI $>30$ events/h, the pooled MD was $5.72 \mathrm{pg} / \mathrm{mL}$ (95\% CI: 4.32, 7.12; $p<0.00001)$, while the pooled MD was $127.01 \mathrm{pg} / \mathrm{mL}$ (95\%CI: $100.56,153.47 ; p<0.00001$ ) in individuals with OSAS and a AHI $\leq 30$ events/h. Thus, serum TNF- $\alpha$ levels were 22.2 times higher, when participants with OSAS had AHI $\leq 30$ events/h, compared to AHI $>30$ events/h.

For plasma TNF- $\alpha$ levels, in individuals with OSAS and AHI $>30$ events $/ \mathrm{h}$, the pooled MD was $8.15 \mathrm{pg} / \mathrm{mL}$ (95\% CI: 5.59, 10.71; $p<0.00001)$, while in individuals with OSAS and AHI $\leq 30$ events/h, the pooled MD was $2.97 \mathrm{pg} / \mathrm{mL}$ (95\% CI: $0.21,5.73 ; p=0.03$ ). Thus, serum TNF- $\alpha$ levels were 2.7 times higher in participants with OSAS and AHI $>30$ events/h, compared to serum TNF- $\alpha$ levels in participants with OSAS and AHI $\leq 30$ events/h.

\subsection{Adult Caucasian Participants}

\subsubsection{Mean BMI of Individuals with OSAS}

For serum TNF- $\alpha$ levels, studies with Caucasian participants with OSAS and a BMI $>30 \mathrm{~kg} / \mathrm{m}^{2}$ showed the pooled MD of $2.58 \mathrm{pg} / \mathrm{mL}$ (95\% CI: 1.07, 4.10; $p=0.0008$ ), whereas for studies with participants with a $\mathrm{BMI} \leq 30 \mathrm{~kg} / \mathrm{m}^{2}$ serum TNF- $\alpha$ levels did not statistically differ between participants with or without OSAS (Table 3).

For plasma TNF- $\alpha$ levels, studies with Caucasian participants with OSAS and a BMI $\leq 30 \mathrm{~kg} / \mathrm{m}^{2}$ showed the pooled MD of $7.99 \mathrm{pg} / \mathrm{mL}$ (95\% CI: 1.84, 14.15; $p=0.01$ ), whereas no significant MDs were observed in studies including Caucasian participants with OSAS and a BMI $>30 \mathrm{~kg} / \mathrm{m}^{2}$.

\subsubsection{Mean BMI of Controls}

For studies with serum TNF- $\alpha$ levels and Caucasian controls with a mean BMI $>30 \mathrm{~kg} / \mathrm{m}^{2}$, the pooled MD was $2.58 \mathrm{pg} / \mathrm{mL}$ (95\% CI: 1.07, 4.10; $p=0.0008$ ). There was no statistically significant MD for serum TNF- $\alpha$ levels between Caucasians with or without OSAS and a mean $\leq 30 \mathrm{~kg} / \mathrm{m}^{2}$.

For studies with plasma TNF- $\alpha$ levels and controls with a BMI $>30 \mathrm{~kg} / \mathrm{m}^{2}$, the pooled MD was $0.56 \mathrm{pg} / \mathrm{mL}$ (95\% CI: $0.05,1.08 ; p=0.03)$. Studies with controls with a BMI $\leq 30 \mathrm{~kg} / \mathrm{m}^{2}$ showed a pooled MD of $5.64 \mathrm{pg} / \mathrm{mL}$ (95\% CI: 0.77, 10.52; 0.02). Thus, plasma TNF- $\alpha$ levels were 10.1 times higher in controls with a BMI $\leq 30 \mathrm{~kg} / \mathrm{m}^{2}$, compared to plasma TNF- $\alpha$ levels of controls with a BMI $>30 \mathrm{~kg} / \mathrm{m}^{2}$

\subsubsection{Total Number of Participants}

Serum TNF- $\alpha$ levels had a significant difference in studies with $\leq 100$ cases (MD $=3.21 \mathrm{pg} / \mathrm{mL}$; $95 \%$ CI: $1.37,5.05 ; p=0.0006$ ), whereas there was no significant difference for studies with $>100$ cases.

\subsubsection{Mean AHI of Individuals with OSAS}

In studies with individuals with OSAS and AHI of $>30$ events/h, serum TNF- $\alpha$ levels were $1.40 \mathrm{pg} / \mathrm{mL}(95 \%$ CI: 0.34, 2.46; $p=0.010)$, and plasma TNF- $\alpha$ levels were 7.80 pg/mL (95\% CI: 2.47, $13.13 ; p=0.004)$.

\subsection{Adult Asian Participants}

\subsubsection{Mean BMI of Individuals with OSAS}

For serum and plasma TNF- $\alpha$ levels, there were no Asian participants with OSAS and a mean BMI $>30 \mathrm{~kg} / \mathrm{m}^{2}$. For studies with Asian participants with OSAS and a mean BMI $\leq 30 \mathrm{~kg} / \mathrm{m}^{2}$, serum 
$(\mathrm{MD}=37.11 \mathrm{pg} / \mathrm{mL} ; 95 \% \mathrm{CI}: 33.27,25.96 ; p<0.0001)$ and plasma (MD = $14.92 \mathrm{pg} / \mathrm{mL} ; 95 \% \mathrm{CI}: 9.86$, 19.98; $p<0.00001)$ TNF- $\alpha$ levels differed statistically significantly (Table 4 ).

Table 3. Subgroup analysis on serum and plasma levels of tumor necrosis factor alpha in adult Caucasian participants.

\begin{tabular}{|c|c|c|c|}
\hline $\begin{array}{l}\text { Subgroup Analysis of } \\
\text { Serum Level }(n)\end{array}$ & $\begin{array}{c}\text { MD }(95 \% \mathrm{CI}), p \text {-Value, } \\
\mathrm{I}^{2}(\%), \mathrm{P}_{\mathrm{h}}\end{array}$ & $\begin{array}{l}\text { Subgroup Analysis of } \\
\text { Plasma Level (n) }\end{array}$ & $\begin{array}{c}\text { MD (95\%CI), } p \text {-Value, } \\
I^{2}(\%), P_{h}\end{array}$ \\
\hline Overall (12) & $\begin{array}{c}2.20(1.06,3.34), 0.0002 \\
94,<0.00001\end{array}$ & Overall (6) & $\begin{array}{c}3.72(1.04,6.40), 0.007 \\
99,<0.00001\end{array}$ \\
\hline $\begin{array}{l}\text { Mean BMI of OSAS } \\
\text { patients, } \mathrm{kg} / \mathrm{m}^{2}\end{array}$ & - & $\begin{array}{l}\text { Mean BMI of OSAS } \\
\text { patients, } \mathrm{kg} / \mathrm{m}^{2}\end{array}$ & - \\
\hline$>30(9)$ & $\begin{array}{c}2.58(1.07,4.10), 0.0008 \\
95,<0.00001\end{array}$ & $>30(4)$ & $\begin{array}{c}0.43(-0.010,0.96), 0.11 \\
50,0.11\end{array}$ \\
\hline$\leq 30(2)$ & $\begin{array}{c}1.70(-0.32,3.71), 0.10 \\
82,0.02\end{array}$ & $\leq 30(2)$ & $\begin{array}{c}7.99(1.84,14.15), 0.01 \\
98,<0.00001\end{array}$ \\
\hline $\begin{array}{l}\text { Mean BMI of } \\
\text { controls, } \mathrm{kg} / \mathrm{m}^{2}\end{array}$ & - & $\begin{array}{l}\text { Mean BMI of } \\
\text { controls, } \mathrm{kg} / \mathrm{m}^{2}\end{array}$ & - \\
\hline$>30(8)$ & $\begin{array}{c}2.28(0.86,3.70), 0.002 \\
95,<0.00001\end{array}$ & $>30(2)$ & $\begin{array}{c}0.56(0.05,1.08), 0.03 \\
18,27\end{array}$ \\
\hline$\leq 30(3)$ & $\begin{array}{c}3.29(-1.09,7.67), 0.14 \\
93,<0.00001\end{array}$ & $\leq 30(4)$ & $\begin{array}{c}5.64(0.77,10.52), 0.02 \\
99,<0.00001\end{array}$ \\
\hline $\begin{array}{l}\text { Total number of } \\
\text { participants }\end{array}$ & - & $\begin{array}{l}\text { Total number of } \\
\text { participants }\end{array}$ & - \\
\hline$>100(3)$ & $\begin{array}{c}1.13(-0.78,3.04), 0.25 \\
91,<0.0001\end{array}$ & $>100$ (3) & $\begin{array}{c}3.82(-0.22,7.85), 0.06 \\
99,<0.00001\end{array}$ \\
\hline$\leq 100(9)$ & $\begin{array}{c}3.21(1.37,5.05), 0.0006 \\
95,<0.00001\end{array}$ & $\leq 100$ & $\begin{array}{c}3.52(0.03,7.02), 0.05 \\
95,<0.00001\end{array}$ \\
\hline $\begin{array}{l}\text { Mean AHI of OSAS } \\
\text { patients, events/h }\end{array}$ & - & $\begin{array}{l}\text { Mean AHI of OSAS } \\
\text { patients, events/h }\end{array}$ & - \\
\hline$>30(8)$ & $\begin{array}{c}1.40(0.34,2.46), 0.010 \\
91,<0.00001\end{array}$ & $>30(3)$ & $\begin{array}{c}7.80(2.47,13.13), 0.004, \\
97,<0.00001\end{array}$ \\
\hline$\leq 30(2)$ & $\begin{array}{c}23.20(-28.02,74.41) \\
0.37,85,0.01\end{array}$ & $\leq 30(3)$ & $\begin{array}{c}0.26(-0.01,0.53), 0.06 \\
34,0.22\end{array}$ \\
\hline
\end{tabular}

BMI, Body mass index; CI, Confidence interval; OSAS, Obstructive sleep apnea syndrome; MD, Mean difference; $\mathrm{P}_{\mathrm{h}}$,

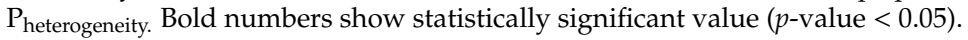

\subsubsection{Mean BMI of Controls}

For serum and plasma TNF- $\alpha$ levels, there were no studies including controls with a BMI $>30 \mathrm{~kg} / \mathrm{m}^{2}$. The serum TNF- $\alpha$ levels were 37.11 pg/mL (95\% CI: 33.27, 25.96; $p<0.0001)$ for studies including OSAS patients with a mean BMI of $\leq 30 \mathrm{~kg} / \mathrm{m}^{2}$, and plasma TNF- $\alpha$ levels were $14.92 \mathrm{pg} / \mathrm{mL}$ (CI: 9.86, 19.98; $p<0.00001$ ) for studies including OSAS patients with a mean BMI of $\leq 30 \mathrm{~kg} / \mathrm{m}^{2}$.

\subsubsection{Total Number of Participants}

For serum TNF- $\alpha$ levels, the pooled MD was 89.88 pg/mL (95\% CI: 74.59, 105.17; $p<0.00001)$ for studies with 100 or more participants, and the pooled MD was $7.80 \mathrm{pg} / \mathrm{mL}$ (95\% CI: 5.76, 9.85; $p<0.00001$ ) for studies less than 100 participants. Thus, serum TNF- $\alpha$ levels were 11.5 times higher in studies with more than 100 participants, compared to studies with less than 100 participants.

For plasma TNF- $\alpha$ levels, the pooled MD was 12.34 pg/mL (95\%CI: 7.84, 16.84; $p<0.00001)$ for studies with 100 or more participants, and the pooled MD was $21.51 \mathrm{pg} / \mathrm{mL}$ (95\%CI: 13.15, 29.87; 
$p<0.00001$ ) for studies less than 100 participants. Thus, plasma TNF- $\alpha$ levels were 1.7 times higher in studies with less than 100 participants, compared to studies with more than 100 participants.

Table 4. Subgroup analysis on serum and plasma levels of tumor necrosis factor alpha in adult Asian participants.

\begin{tabular}{|c|c|c|c|}
\hline $\begin{array}{l}\text { Subgroup Analysis of } \\
\text { Serum Level }(n)\end{array}$ & $\begin{array}{c}\text { MD }(95 \% C I), p \text {-Value, } \\
I^{2}(\%), P_{h}\end{array}$ & $\begin{array}{l}\text { Subgroup Analysis of } \\
\text { Plasma Level }(n)\end{array}$ & $\begin{array}{c}\text { MD }(95 \% C I), p \text {-Value, } \\
I^{2}(\%), P_{h}\end{array}$ \\
\hline Overall (12) & $\begin{array}{c}37.11(33.27,40.95) \\
<0.00001,100,<0.00001\end{array}$ & Overall (7) & $\begin{array}{c}14.92(9.86,19.98) \\
<0.00001,100,<0.00001\end{array}$ \\
\hline $\begin{array}{l}\text { Mean BMI of OSAS } \\
\text { patients, } \mathrm{kg} / \mathrm{m}^{2}\end{array}$ & - & $\begin{array}{l}\text { Mean BMI of OSAS } \\
\text { patients, } \mathrm{kg} / \mathrm{m}^{2}\end{array}$ & - \\
\hline$>30(0)$ & - & $>30(0)$ & - \\
\hline$\leq 30(12)$ & $\begin{array}{c}37.11(33.27,40.95) \\
<0.00001,100,<0.00001\end{array}$ & $\leq 30(7)$ & $\begin{array}{c}14.92(9.86,19.98) \\
<0.00001,100,<0.00001\end{array}$ \\
\hline $\begin{array}{l}\text { Mean BMI of } \\
\text { controls, } \mathrm{kg} / \mathrm{m}^{2}\end{array}$ & - & $\begin{array}{c}\text { Mean BMI of } \\
\text { controls, } \mathrm{kg} / \mathrm{m}^{2}\end{array}$ & - \\
\hline$>30(0)$ & - & $>30(0)$ & - \\
\hline$\leq 30(12)$ & $\begin{array}{c}37.11(33.27,40.95) \\
<0.00001,100,<0.00001\end{array}$ & $\leq 30(7)$ & $\begin{array}{c}14.92(9.86,19.98) \\
<0.00001,100,<0.00001\end{array}$ \\
\hline $\begin{array}{l}\text { Total number of } \\
\text { participants }\end{array}$ & - & $\begin{array}{l}\text { Total number of } \\
\text { participants }\end{array}$ & - \\
\hline$>100(6)$ & $\begin{array}{c}89.88(74.59,105.17) \\
<0.00001,100,<0.00001\end{array}$ & $>100(3)$ & $\begin{array}{c}12.34(7.84,16.84) \\
<0.00001,97,<0.00001\end{array}$ \\
\hline$\leq 100(6)$ & $\begin{array}{c}7.80(5.76,9.85) \\
<0.00001,99,<0.00001\end{array}$ & $\leq 100$ & $\begin{array}{c}21.51(13.15,29.87) \\
<0.00001,99,<0.00001\end{array}$ \\
\hline $\begin{array}{l}\text { Mean AHI of OSAS } \\
\text { patients, events/h }\end{array}$ & - & $\begin{array}{l}\text { Mean AHI of OSAS } \\
\text { patients, events/h }\end{array}$ & - \\
\hline$>30(9)$ & $\begin{array}{c}12.94(7.74,18.13) \\
<0.00001,100,<0.00001\end{array}$ & $>30(4)$ & $\begin{array}{c}12.48(17.04,31.52) \\
<0.00001,100,<0.00001\end{array}$ \\
\hline$\leq 30(0)$ & - & $\leq 30$ & $\begin{array}{c}5.45(-3.55,14.45), 0.24 \\
99,<0.00001\end{array}$ \\
\hline
\end{tabular}

BMI, Body mass index; CI, Confidence interval; OSAS, Obstructive sleep apnea syndrome; MD, Mean difference; $\mathrm{P}_{\mathrm{h}}$,

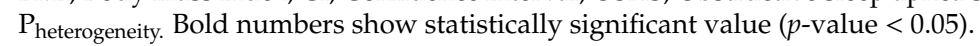

\subsubsection{Mean AHI of Individuals with OSAS}

No study investigated serum and plasma TNF- $\alpha$ levels in participants with OSAS with a mean $\mathrm{AHI} \leq 30$ events/h.

For studies including AHI > 30 events $/ \mathrm{h}$, mean serum TNF- $\alpha$ levels were 12.94 (pg/mL; $95 \%$ CI: 7.74, 18.13; $p<0.00001)$; plasma TNF- $\alpha$ levels were 12.48 pg/mL (95\% CI: 17.04, 31.52; $p<0.00001$ ).

\subsection{Adult Participants Including Mean BMI of Individuals with OSAS $>30 \mathrm{~kg} / \mathrm{m}^{2}$}

\subsubsection{Mean BMI of Controls}

For studies with serum TNF- $\alpha$ levels and controls with BMI of controls $>30 \mathrm{~kg} / \mathrm{m}^{2}$, there was a significant difference for serum TNF- $\alpha$ levels (MD $=2.28 \mathrm{pg} / \mathrm{mL} ; 95 \% \mathrm{CI}: 0.86,3.70 ; p=0.002$ ), compared to studies with controls with BMI of controls $\leq 30 \mathrm{~kg} / \mathrm{m}^{2}$ (Table 5). 
Table 5. Subgroup analysis on serum and plasma levels of tumor necrosis factor alpha in adult participants including mean BMI of OSAS patients $>30 \mathrm{~kg} / \mathrm{m}^{2}$.

\begin{tabular}{|c|c|c|c|}
\hline $\begin{array}{l}\text { Subgroup Analysis of } \\
\text { Serum Level }(n)\end{array}$ & $\begin{array}{c}\text { MD (95\%CI), } p \text {-Value, } \\
\mathrm{I}^{2}(\%), \mathrm{P}_{\mathrm{h}}\end{array}$ & $\begin{array}{l}\text { Subgroup Analysis of } \\
\text { Plasma Level }(n)\end{array}$ & $\begin{array}{c}\text { MD (95\%CI), } p \text {-Value, } \\
I^{2}(\%), P_{h}\end{array}$ \\
\hline Overall (11) & $\begin{array}{c}1.27(0.67,1.86) \\
<0.0001,95,<0.000001\end{array}$ & Overall (7) & $\begin{array}{c}1.06(0.34,1.78), 0.004 \\
91,<0.00001\end{array}$ \\
\hline $\begin{array}{l}\text { Mean BMI of } \\
\text { controls, } \mathrm{kg} / \mathrm{m}^{2}\end{array}$ & - & $\begin{array}{c}\text { Mean BMI of } \\
\text { controls, } \mathrm{kg} / \mathrm{m}^{2}\end{array}$ & - \\
\hline$>30(8)$ & $\begin{array}{c}2.28(0.86,3.70), 0.002 \\
95,<0.00001\end{array}$ & $>30(4)$ & $\begin{array}{c}1.19(0.00,2.38), 0.05 \\
92,<0.00001\end{array}$ \\
\hline$\leq 30(3)$ & $\begin{array}{c}40.64(-24.23,105.51) \\
0.22,92,<0.00001\end{array}$ & $\leq 30(3)$ & $\begin{array}{c}0.88(-0.30,2.07), 0.14 \\
93,<0.00001\end{array}$ \\
\hline $\begin{array}{l}\text { Total number } \\
\text { of participants }\end{array}$ & - & $\begin{array}{l}\text { Total number } \\
\text { of participants }\end{array}$ & - \\
\hline$>100(2)$ & $\begin{array}{c}34.66(-34.62,103.93) \\
0.33,95,<0.00001\end{array}$ & $>100(2)$ & $\begin{array}{c}0.20(-0.09,0.48), 0.17 \\
0,0.53\end{array}$ \\
\hline$\leq 100(9)$ & $\begin{array}{c}1.27(0.65,1.89) \\
<0.0001,95,<0.00001\end{array}$ & $\leq 100(5)$ & $\begin{array}{c}1.51(0.53,2.49), 0.003 \\
90,<0.00001\end{array}$ \\
\hline $\begin{array}{l}\text { Mean AHI of OSAS } \\
\text { patients, events/h }\end{array}$ & - & $\begin{array}{l}\text { Mean AHI of OSAS } \\
\text { patients, events/h }\end{array}$ & - \\
\hline$>30(9)$ & $\begin{array}{c}0.96(0.50,1.42) \\
<0.0001,92,<0.00001\end{array}$ & $>30(4)$ & $\begin{array}{c}1.69(0.47,2.90), 0.007 \\
92,<0.00001\end{array}$ \\
\hline$\leq 30(2)$ & $\begin{array}{l}42.13(33.48,50.77) \\
<0.00001,0,0.58\end{array}$ & $\leq 30(3)$ & $\begin{array}{c}0.26(-0.01,0.53), 0.06 \\
34,0.22\end{array}$ \\
\hline
\end{tabular}

BMI, Body mass index; CI, Confidence interval; OR, OSAS, Obstructive sleep apnea syndrome; MD, Mean difference;

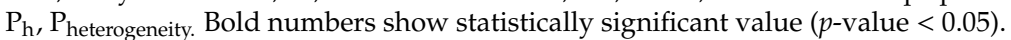

\subsubsection{Total Number of Participants}

For studies with 100 or less participants, there was a significant difference for serum TNF- $\alpha$ levels $(\mathrm{MD}=1.27 \mathrm{pg} / \mathrm{mL} ; 95 \%$ CI: $0.65,1.89 ; p<0.0001)$ and for plasma TNF- $\alpha$ levels $(\mathrm{MD}=1.51 \mathrm{pg} / \mathrm{mL}$; $95 \%$ CI: $0.53,2.49 ; p=0.003)$, compared to studies with more than 100 participants.

\subsubsection{Mean AHI of Participants with OSAS}

For serum TNF- $\alpha$ levels, the pooled MD for studies including participants with OSAS with AHI $>30$ events/h was $0.96 \mathrm{pg} / \mathrm{mL}$ (95\% CI: 0.50, 1.42; $p<0.0001)$; the pooled MD for studies with participants with OSAS with AHI $\leq 30$ events/h was $42.13 \mathrm{pg} / \mathrm{mL}(95 \% \mathrm{CI}: 33.48,50.77 ; p<0.00001)$. Thus, serum TNF- $\alpha$ levels were 42.9 times higher in studies with participants with OSAS and AHI $\leq 30$ events/h, compared to the serum TNF- $\alpha$ levels in studies including participants with OSAS and $\mathrm{AHI}>30$ events/h.

For plasma TNF- $\alpha$ levels, the pooled MD for studies with participants with OSAS with AHI $>30$ events $/ \mathrm{h}$ was $1.69 \mathrm{pg} / \mathrm{mL}(95 \% \mathrm{CI}: 0.47,2.90 ; p=0.007)$. When studies included participants with OSAS and an AHI $\leq 30$ events/h, MDs between studies with participants with or without OSAS were not significant.

\subsection{Adult Participants with a Mean BMI $\leq 30 \mathrm{~kg} / \mathrm{m}^{2}$ in Participants with OSAS}

\subsubsection{Mean BMI of Controls}

No study investigated serum and plasma TNF- $\alpha$ levels in participants with OSAS with a mean BMI $>30 \mathrm{~kg} / \mathrm{m}^{2}$. 
For studies including BMI $\leq 30 \mathrm{~kg} / \mathrm{m}^{2}$ in controls, TNF- $\alpha$ levels were $23.07 \mathrm{pg} / \mathrm{mL}$ (95\% CI: 20.18, 4.50; $p<0.00001)$ for serum, and MD $=10.82 \mathrm{pg} / \mathrm{mL}(95 \% \mathrm{CI}: 7.14,14.49 ; p<0.00001)$ for plasma (Table 6).

Table 6. Subgroup analysis on serum and plasma levels of tumor necrosis factor alpha in adult participants including mean BMI of OSAS patients $\leq 30 \mathrm{~kg} / \mathrm{m}^{2}$.

\begin{tabular}{|c|c|c|c|}
\hline $\begin{array}{l}\text { Subgroup Analysis of } \\
\text { Serum Level }(n)\end{array}$ & $\begin{array}{c}\text { MD }(95 \% \mathrm{CI}), p \text {-Value, } \\
\mathrm{I}^{2}(\%), \mathrm{P}_{\mathrm{h}}\end{array}$ & $\begin{array}{l}\text { Subgroup Analysis of } \\
\text { Plasma Level (n) }\end{array}$ & $\begin{array}{c}\text { MD (95\%CI), } p \text {-Value, } \\
\mathrm{I}^{2}(\%), \mathrm{P}_{\mathrm{h}}\end{array}$ \\
\hline Overall (17) & $\begin{array}{c}23.07(20.18,4.50) \\
<0.00001,100,<0.00001\end{array}$ & Overall (10) & $\begin{array}{c}10.82(7.14,14.49) \\
<0.00001,99,<0.00001\end{array}$ \\
\hline $\begin{array}{c}\text { Mean BMI of } \\
\text { controls, } \mathrm{kg} / \mathrm{m}^{2}\end{array}$ & - & $\begin{array}{c}\text { Mean BMI of } \\
\text { controls, } \mathrm{kg} / \mathrm{m}^{2}\end{array}$ & - \\
\hline$>30(0)$ & - & $>30(0)$ & - \\
\hline$\leq 30(17)$ & $\begin{array}{c}23.07(20.18,4.50) \\
<0.00001,100,<0.00001\end{array}$ & $\leq 30(10)$ & $\begin{array}{c}10.82(7.14,14.49) \\
<0.00001,99,<0.00001\end{array}$ \\
\hline $\begin{array}{l}\text { Total number } \\
\text { of participants }\end{array}$ & - & $\begin{array}{l}\text { Total number } \\
\text { of participants }\end{array}$ & - \\
\hline$>100(8)$ & $\begin{array}{c}63.51(53.65,73.45) \\
<0.00001,100,<0.00001\end{array}$ & $>100$ (6) & $\begin{array}{c}8.12(4.46,11.79) \\
<0.0001,98,<0.00001\end{array}$ \\
\hline$\leq 100(9)$ & $\begin{array}{c}4.42(3.10,5.74) \\
<0.00001,98,<0.00001\end{array}$ & $\leq 100(4)$ & $\begin{array}{c}13.79(8.24,19.35) \\
<0.00001,99,<0.00001\end{array}$ \\
\hline $\begin{array}{l}\text { Mean AHI of OSAS } \\
\text { patients, events/h }\end{array}$ & - & $\begin{array}{l}\text { Mean AHI of OSAS } \\
\text { patients, events/h }\end{array}$ & - \\
\hline$>30(9)$ & $\begin{array}{c}12.94(7.74,18.13) \\
<0.00001,100,<0.00001\end{array}$ & $>30(6)$ & $\begin{array}{c}16.13(11.20,21.06) \\
<0.00001,100,<0.00001\end{array}$ \\
\hline$\leq 30(3)$ & $\begin{array}{l}173.00(139.66,206.34) \\
<0.00001,100,<0.00001\end{array}$ & $\leq 30$ & $\begin{array}{c}5.45(-3.55,14.45), 0.24 \\
99,<0.00001\end{array}$ \\
\hline
\end{tabular}

BMI, Body mass index; CI, Confidence interval; OR, OSAS, Obstructive sleep apnea syndrome; MD, Mean difference;

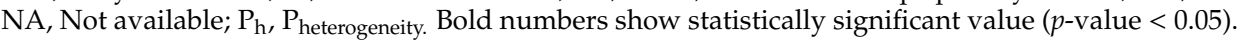

\subsubsection{Total Number of Participants}

For serum TNF- $\alpha$ levels and in studies with more than 100 participants, the pooled MD was $63.51 \mathrm{pg} / \mathrm{mL}$ (95\% CI: 53.65, 73.45; $p<0.00001)$, while in studies with $\leq 100$ participants, the pooled MD was $4.42 \mathrm{pg} / \mathrm{mL}$ (95\% CI: 3.10, 5.74; $p<0.00001$ ). Thus, serum TNF- $\alpha$ levels were 14.4 times higher in studies with more than 100 participants, compared to serum TNF- $\alpha$ levels in studies with $\leq 100$ participants.

For plasma TNF- $\alpha$ levels and in studies with more than 100 participants, the pooled MD was $8.12 \mathrm{pg} / \mathrm{mL}$ (95\%CI: 4.46, 11.79; $p<0.0001$ ) while in studies with $\leq 100$ participants, the pooled MD $13.79 \mathrm{pg} / \mathrm{mL}$ (95\%CI: 8.24, 19.35; $p<0.00001$ ). Thus, plasma TNF- $\alpha$ levels were 1.7 times higher in studies with more than 100 participants, compared to plasma TNF- $\alpha$ levels in studies with $\leq 100$ participants.

\subsubsection{Mean AHI of Participants with OSAS}

For serum TNF- $\alpha$ levels, the pooled MD for studies including participants with OSAS and an AHI $>30$ events/h was $12.94 \mathrm{pg} / \mathrm{mL}$ (95\% CI: 7.74, 18.13; $p<0.00001)$; the pooled MD for studies including participants with OSAS and an AHI $\leq 30$ events/h was $173.00 \mathrm{pg} / \mathrm{mL}(95 \% \mathrm{CI}: 139.66,206.34 ; p<0.00001)$. Thus, serum TNF- $\alpha$ levels were 13.4 times higher in participants with OSAS and AHI $\leq 30$ events/h, compared to the serum TNF- $\alpha$ levels in participants with OSAS and AHI $>30$ events/h.

For plasma TNF- $\alpha$ levels, the pooled MD for studies including participants with OSAS and an AHI > 30 events/h was $16.13 \mathrm{pg} / \mathrm{mL}$ (95\% CI: 11.20, 21.06; $p<0.00001)$. When studies included participants with OSAS had an AHI $\leq 30$ events/h, MDs between studies including participants with or without OSAS were not significant. 


\subsection{Meta-Regression}

The results of meta-regression showed that age, the publication year, the mean BMI, the mean $\mathrm{AHI}$, and the number of participants did not systematically change serum and plasma TNF- $\alpha$ levels (Table 7).

Table 7. Meta-regression analysis based on some variables for serum and plasma levels of tumor necrosis factor alpha in obstructive sleep apnea syndrome patients compared with controls in adult participants.

\begin{tabular}{|c|c|c|c|c|c|c|c|c|c|c|c|}
\hline $\begin{array}{c}\text { Year of } \\
\text { Publication }\end{array}$ & $\mathbf{R}$ & Adjusted $\mathbf{R}^{2}$ & $p$ & $\begin{array}{l}\text { Mean Age of } \\
\text { OSAS Patients }\end{array}$ & $\mathbf{R}$ & Adjusted $R^{2}$ & $p$ & $\begin{array}{c}\text { Mean Age } \\
\text { of Controls }\end{array}$ & $\mathbf{R}$ & Adjusted $\mathrm{R}^{2}$ & $p$ \\
\hline Serum & 0.014 & -0.036 & 0.942 & Serum & 0.111 & -0.024 & 0.567 & Serum & 0.081 & -0.030 & 0.678 \\
\hline Plasma & 0.384 & 0.091 & 0.128 & Plasma & 0.018 & -0.066 & 0.946 & Plasma & 0.079 & -0.060 & 0.764 \\
\hline $\begin{array}{l}\text { Mean BMI of } \\
\text { OSAS patients }\end{array}$ & $\mathrm{R}$ & Adjusted $\mathrm{R}^{2}$ & $p$ & $\begin{array}{l}\text { Mean BMI } \\
\text { of controls }\end{array}$ & $\mathrm{R}$ & Adjusted $R^{2}$ & $p$ & $\begin{array}{l}\text { Mean AHI of } \\
\text { OSAS patients }\end{array}$ & $\mathrm{R}$ & Adjusted $\mathrm{R}^{2}$ & $p$ \\
\hline Serum & 0.122 & -0.025 & 0.545 & Serum & 0.159 & -0.014 & 0.429 & Serum & 0.339 & 0.075 & 0.105 \\
\hline Plasma & 0.201 & -0.024 & 0.439 & Plasma & 0.292 & 0.024 & 0.256 & Plasma & 0.126 & -0.054 & 0.641 \\
\hline $\begin{array}{l}\text { Number of } \\
\text { participants }\end{array}$ & $\mathrm{R}$ & Adjusted $\mathrm{R}^{2}$ & $p$ & - & - & - & - & - & - & - & - \\
\hline Serum & 0.004 & -0.36 & 0.985 & - & - & - & - & - & - & - & \\
\hline Plasma & 0.202 & -0.023 & 0.438 & - & - & - & - & - & - & - & - \\
\hline
\end{tabular}

\subsection{Quality Assessment}

The quality score of each study included in the meta-analysis is illustrated in Table 8.

Table 8. Quality assessment scores of the studies involved in the meta-analysis.

\begin{tabular}{|c|c|c|c|c|}
\hline The First Author, Year & Selection & Comparability & Exposure & Total Points \\
\hline \multicolumn{5}{|c|}{ Adults } \\
\hline Vgontzas, 1997 [28] & $* * *$ & - & $* * *$ & 6 \\
\hline Huiguo, 2000 [29] & $* * *$ & $* *$ & $* * *$ & 8 \\
\hline Vgontzas, 2000 [30] & $* * *$ & $* *$ & $* * *$ & 8 \\
\hline Ciftci, 2004 [31] & $* * *$ & $* *$ & $* * *$ & 8 \\
\hline Imagawa, 2004 [32] & $* * *$ & $*$ & $* * *$ & 7 \\
\hline Minoguchi, 2004 [16] & $* * *$ & $* *$ & $* * *$ & 8 \\
\hline Tazaki, 2004 [33] & $* * *$ & $* *$ & $* * *$ & 8 \\
\hline Ryan, 2005 [34] & $* * *$ & $* *$ & $* * *$ & 8 \\
\hline Kobayashi, 2006 [35] & $* * *$ & $* *$ & $* * *$ & 8 \\
\hline Ryan, 2006 [36] & $* * *$ & $* *$ & $* * *$ & 8 \\
\hline de la Peña Bravo, 2007 [38] & $* * *$ & $* *$ & $* * *$ & 8 \\
\hline Arias, 2008 [39] & $* * *$ & ** & $* * *$ & 8 \\
\hline Constantinidis, 2008 [40] & $* * *$ & $* *$ & $* * *$ & 8 \\
\hline Kanbay, 2008 [41] & $* * *$ & $* *$ & $* * *$ & 8 \\
\hline Tomiyama, 2008 [43] & $* * *$ & $* *$ & $* * *$ & 8 \\
\hline Carneiro, 2009 [44] & $* * *$ & * & $* * *$ & 7 \\
\hline Li, $2009[45]$ & $* * *$ & $* *$ & $* * *$ & 8 \\
\hline Thomopoulos, 2009 [46] & $* * *$ & $* *$ & $* * *$ & 8 \\
\hline Sahlman, 2010 [47] & $* * *$ & $* *$ & $* * *$ & 8 \\
\hline Steiropoulos, 2010 [48] & $* * *$ & $* *$ & $* * *$ & 8 \\
\hline Sarac, 2011 [49] & $* * *$ & * & $* * *$ & 7 \\
\hline Fornadi, 2012 [50] & $* * *$ & $* *$ & $* * *$ & 8 \\
\hline Medeiros, 2012 [51] & $* * *$ & ** & $* * *$ & 8 \\
\hline Qian, 2012 [52] & $* * *$ & $* *$ & $* * *$ & 8 \\
\hline
\end{tabular}


Table 8. Cont.

\begin{tabular}{|c|c|c|c|c|}
\hline The First Author, Year & Selection & Comparability & Exposure & Total Points \\
\hline Chen, 2013 [54] & $* * *$ & * & $* * *$ & 7 \\
\hline Hargens, 2013 [56] & $* * *$ & $* *$ & $* * *$ & 8 \\
\hline Matos, 2013 [57] & $* * *$ & $* *$ & $* * *$ & 8 \\
\hline Yang, 2013 [58] & $* * *$ & $* *$ & $* * *$ & 8 \\
\hline Ciccone, 2014 [59] & $* * *$ & $* *$ & $* * *$ & 8 \\
\hline Sun, 2014 [60] & $* * *$ & $* *$ & $* * *$ & 8 \\
\hline Unuvar Dogan, 2014 [61] & $* * *$ & $* *$ & $* * *$ & 8 \\
\hline Chen, 2015 [62] & $* * *$ & $* *$ & $* * *$ & 8 \\
\hline De, 2015 [63] & $* * *$ & $* *$ & $* * *$ & 8 \\
\hline Jiang, 2015 [64] & $* * *$ & $* *$ & $* * *$ & 8 \\
\hline Thunström, 2015 [65] & $* * * *$ & ** & $* * *$ & 9 \\
\hline Lin, $2016[67]$ & $* * *$ & ** & $* * *$ & 8 \\
\hline Nizam, 2016 [68] & $* * *$ & $* *$ & $* * *$ & 8 \\
\hline Vicente, 2016 [69] & $* * *$ & ** & $* * *$ & 8 \\
\hline Hirotsu, 2017 [70] & $* * * *$ & ** & $* * *$ & 9 \\
\hline Jiang, 2017 [71] & $* * *$ & * & $* * *$ & 7 \\
\hline Jin, 2017 [72] & $* * *$ & ** & $* * *$ & 8 \\
\hline Bozic, 2018 [75] & $* * *$ & $* *$ & $* * *$ & 8 \\
\hline Kong, 2018 [76] & $* * *$ & ** & $* * *$ & 8 \\
\hline Ming, 2019 [78] & $* * *$ & * & $* * *$ & 7 \\
\hline Tang, 2019 [79] & $* * *$ & ** & $* * *$ & 8 \\
\hline Galati, 2020 [80] & $* * * *$ & $* *$ & $* * *$ & 9 \\
\hline \multicolumn{5}{|c|}{ Children } \\
\hline Tam, 2006 [37] & $* * * *$ & $* *$ & $* * *$ & 9 \\
\hline Li, 2008 [42] & $* * *$ & $*$ & $* * *$ & 7 \\
\hline Alexopoulos, 2013 [53] & $* * *$ & * & $* * *$ & 7 \\
\hline $\mathrm{Chu}, 2013$ [55] & $* * *$ & - & $* * *$ & 6 \\
\hline Gaines, 2016 [66] & $* * *$ & * & $* * *$ & 7 \\
\hline Huang, 2016 [14] & $* * *$ & * & $* * *$ & 7 \\
\hline Smith, 2017 [73] & $* * *$ & * & $* * *$ & 7 \\
\hline Zhang, 2017 [74] & $* * *$ & * & $* * *$ & 7 \\
\hline Rogers, 2018 [77] & $* * *$ & $*$ & $* * *$ & 7 \\
\hline
\end{tabular}

Each asterisk $\left(^{*}\right)$ denotes 1 point.

\subsection{Sensitivity Analysis}

The "cumulative analysis" and the "one study removed" as two sensitivity analyses showed the stability of the results. In addition, excluding statistically the studies with outliers data did not change pooled analysis of serum (MD $=4.53 \mathrm{pg} / \mathrm{mL}, p<0.00001)$ and plasma $(\mathrm{MD}=4.18 \mathrm{pg} / \mathrm{mL}, p<0.00001)$ TNF- $\alpha$ levels (Table 9).

Table 9. Sensitivity analysis on the results of serum and plasma levels in adults participants.

\begin{tabular}{cccccccc}
\hline First Author, Year & Sample & Reason for Removing & MD (95\%CI) & $\mathbf{Z}$ & $p$-Value & $\mathbf{I}^{\mathbf{2}}$ & $\mathbf{P}_{\mathbf{h}}$ \\
\hline Jiang, 2015 [64] & Serum & Outlier data & $4.53(3.48,5.57)$ & 8.87 & $<0.00001$ & 100 & $<0.00001$ \\
Huiguo, 2000 [29] & Plasma & Outlier data & $4.18(2.58,5.78)$ & 5.11 & $<0.00001$ & 99 & $<0.00001$ \\
\hline
\end{tabular}

$\mathrm{CI}$, Confidence interval; MD, Mean difference; $\mathrm{P}_{\mathrm{h}}, \mathrm{P}_{\text {heterogeneity. }}$

\subsection{Publication Bias}

Figure 6 shows the funnel plots of the analysis of serum and plasma TNF- $\alpha$ levels and Table 10 illustrates the results of trim-and-fill method on bias. 


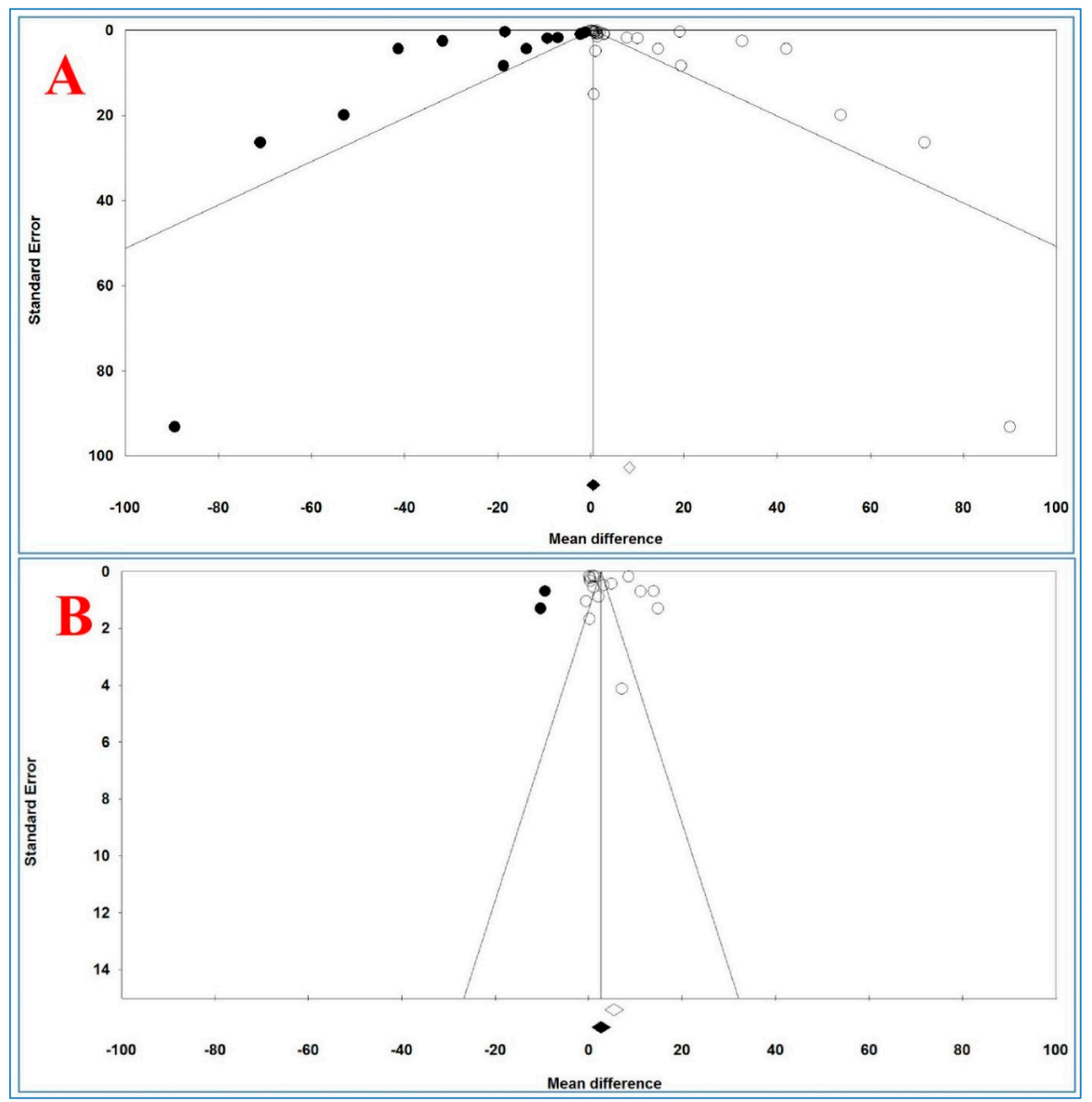

Figure 6. Funnel plot of analysis of tumor necrosis factor alpha levels in adult participants on (A) serum and (B) plasma in adult participants. Open circles represent observed studies. Black circles represent imputed studies. Open diamond represents the pooled effects from the original studies. Black diamond represents the pooled effects incorporating the imputed studies.

Table 10. The results of trim-and-fill method.

\begin{tabular}{|c|c|c|c|c|c|c|c|c|c|}
\hline \multirow[b]{2}{*}{ Sample } & \multirow[b]{2}{*}{ Value } & \multirow[b]{2}{*}{$\begin{array}{l}\text { Studies } \\
\text { Trimmed }\end{array}$} & \multicolumn{3}{|c|}{ Fixed-Effects } & \multicolumn{3}{|c|}{ Random-Effects } & \multirow[b]{2}{*}{$Q$ Value } \\
\hline & & & $\begin{array}{c}\text { Point } \\
\text { Estimate }\end{array}$ & $\begin{array}{l}\text { Lower } \\
\text { Limit }\end{array}$ & $\begin{array}{l}\text { Upper } \\
\text { Limit }\end{array}$ & $\begin{array}{c}\text { Point } \\
\text { Estimate }\end{array}$ & $\begin{array}{l}\text { Lower } \\
\text { Limit }\end{array}$ & $\begin{array}{l}\text { Upper } \\
\text { Limit }\end{array}$ & \\
\hline \multirow{2}{*}{ Serum } & Observed & - & 0.40992 & 0.36474 & 0.45509 & 8.24489 & 7.00639 & 9.48339 & 8710.33950 \\
\hline & Adjusted & 15 & 0.32271 & 0.27770 & 0.36771 & 0.52315 & -0.88882 & 1.93512 & 17050.9022 \\
\hline \multirow{2}{*}{ Plasma } & Observed & - & 2.46259 & 2.32314 & 2.60204 & 5.45206 & 3.50092 & 7.40320 & 2508.21501 \\
\hline & Adjusted & 3 & 2.29455 & 2.15605 & 2.43306 & 2.66813 & 0.63833 & 4.69794 & 3161.99635 \\
\hline
\end{tabular}

For serum levels, Egger's and Begg's tests ( $p=0.02431$ and $p=0.04677$, respectively) revealed a publication bias. For plasma TNF- $\alpha$ levels, Begg's test $(p=0.03943)$ revealed a publication bias, but Egger's test $(p=0.19315)$ did not show any bias between and across the studies.

For serum TNF- $\alpha$ levels and 15 imputed studies, under the fixed-effects model, the point estimate and pseudo $95 \%$ CI for the combined studies was $0.410(0.365,0.455)$; using the trim-fill method, the imputed point estimate was $0.323(0.278,0.368)$. In addition, under the random-effects model, the point estimate and $95 \% \mathrm{CI}$ for the combined studies was $8.245(7.006,9.483)$; using the trim-fill method, the imputed point estimate was $0.523(-0.889,1.935)$.

For plasma TNF- $\alpha$ levels and 3 imputed studies, under the fixed-effects model, the point estimate and $95 \% \mathrm{CI}$ for the combined studies was $2.463(2.323,2.602)$, and using trim-fill method, the imputed point estimate was $2.294(2.156,2.433)$. In addition, under the random-effects model, the point estimate 
and pseudo $95 \%$ CI for the combined studies was 5.452 (3.501, 7.403); using the trim-fill method, the imputed point estimate was $2.668(0.638,4.698)$.

The overall effect sizes on serum and plasma TNF- $\alpha$ levels reported in the forest plot appeared valid, with trivial publication bias effect based on fixed-effects model, because the observed estimates were similar to the adjusted estimates. In contrast, the overall effect sizes on serum and plasma TNF- $\alpha$ levels reported in the forest plot appeared invalid, with significant publication bias effect based on random-effects model, because the observed estimates had high difference with the adjusted estimates.

\section{Discussion}

The present meta-analysis with 55 studies evaluated the serum TNF- $\alpha$ levels ( 29 studies of adults and 4 studies of children) and plasma TNF- $\alpha$ levels (17 studies of adults and 5 studies of children) in individuals with OSAS, compared to controls. The results showed that plasma and serum TNF- $\alpha$ levels in adult individuals with OSAS were significantly higher than the corresponding levels of control. For children with OSAS serum TNF- $\alpha$ levels, but not plasma TNF- $\alpha$ levels, were statistically significantly higher than those of controls. The present results have clinical importance because elevated serum and plasma TNF- $\alpha$ levels can be a risk factor for the development of further systemic diseases in adults with OSAS. Further, more generally, inflammation may play a crucial role in the pathogenesis of OSAS, and there is evidence that individuals with OSAS have elevated interleukin TNF- $\alpha[16,29,40,41,45,48,62,78]$. These conclusions also have practical importance because, in addition to routine checks on sleep and sleep-disordered breathing, both children and adults with OSAS need a thorough monitoring of their immune systems.

Elevated TNF- $\alpha$ levels have been associated with the pathophysiology of reoxygenation injury, myocarditis, cardiac allograft vasculopathy, heart failure progression [81], arthritis, diabetes, Crohn's disease, and also cachexia which correlated with terminal malignancy and AIDS [82]. Further, TNF- $\alpha$ is a well-known inflammatory marker, besides being related to atherosclerosis in males [83]. It is also confirmed that hypoxia raises the expression of proinflammatory molecules such TNF- $\alpha[84,85]$.

The present pattern of results also sheds some light on further new findings: More specifically, for adults, it turned out that compared to healthy controls, TNF- $\alpha$ levels were higher both in blood serum and blood plasma. It follows that at least for adults with OSAS, assessing either blood plasma or blood serum does not appear to be of clinical importance. In contrast, for pediatric samples and compared to healthy controls, higher TNF- $\alpha$ levels were observed for blood serum but not for blood plasma. The quality of the data at hand does not allow a deeper understanding of the underlying physiological mechanisms. Thus, for want of such data, the following admittedly speculative assumptions are advanced. First, it is conceivable that for pediatric samples, the number of four studies on plasma TNF- $\alpha$ was too small, and therefore, the statistical variance of plasma TNF- $\alpha$ was blurred by sample size inconsistencies. Similarly, second, at least among adults, Hirotsu et al. [70] showed that OSAS and inflammatory markers such as IL- 6 and TNF- $\alpha$ were associated with gender in a very complex fashion. A closer inspection of the four studies on plasma TNF- $\alpha$ among pediatric samples showed that gender was not introduced as a specific factor or confounder. Given this lack of analyses in these publications, possible gender effects could neither be confirmed, nor declined. Third, Imani et al. [86] showed that for pediatric samples, the definition of OSAS was not applied as strict and consistent as among adult samples. It follows that the zero-differences of plasma TNF- $\alpha$ between children with and without OSAS might mirror inconsistencies as regards the definition of control samples. Fourth, Cameron et al. [87] observed that besides the disease status, in pediatric samples with Inflammatory Bowel Disease, the outcome of an antitumor necrosis factor (TNF) therapy depended from participants' pubertal stage. Given this, it is conceivable that the zero-difference of plasma TNF- $\alpha$ between pediatric samples with and without OSAS might have been blurred by the pubertal stage. In the same vein, fifth, it is conceivable that pubertal stage and its implicit growth spurt in height and weight might have obscured a clear-cut pattern of results as regards TNF- $\alpha$ levels between children with and without OSAS. Last, even if highly unlikely, one cannot rule out that the pattern of results is an accidental finding. 
The pattern of results described in the present meta-analysis and systematic review consistently showed that higher TNF- $\alpha$ levels were associated with pathologically higher BMI scores as a proxy of obesity. Given that above all childhood overweight and childhood obesity is increasing worldwide and is a major concern of public health [88], the association between overweight/obesity, TNF- $\alpha$ levels and OSAS demand particular attention. Following Popa et al. [13], TNF-alpha appeared to be of upmost importance in the development and maintenance of metabolic diseases in which a shift toward a proatherogenic lipid profile and impaired glucose tolerance appeared to occur. Further, investigations assessing the impact of anti-TNF agents on intermediary metabolism seemed to show that a TNF-alpha blockade may improve insulin resistance and lipid profiles, which in turn appeared to be associated with overweight and obesity. Likewise, Ciftci et al. [31] showed in their study that compared to obese males with no OSAS, in obese males with OSAS TNF-alpha levels were significantly higher. Ciftci et al. [31] concluded from their results, that the association between cardiovascular morbidity and OSAS appeared to be best described by the coexistence of other cardiovascular risk factors such as circulating IL-6 and TNF-alpha levels. In the same vein, Sahlman et al. [47] showed in their study that pro-inflammatory markers such as TNF-alpha were markedly increased in patients with mild OSAS. To find a physiological explanation for such processes, Steiropoulos et al. [48] summarized in their introduction that besides the role of energy depot adipose tissue is also an active endocrine organ, releasing proinflammatory cytokines such as Tumor Necrosis Factor- $\alpha$ (TNF- $\alpha$ ) and Interleukin-6 (IL-6) which modulate blood pressure, and lipid- and glucose-metabolism. Further, the proinflammatory transcription factor NF- $\mathrm{kB}$ appears to be upregulated in OSAS as a result of alterations between hypoxia and reoxygenation and as a result of sleep deprivation. Additionally, NF- $\mathrm{kB}$ regulates the expression of inflammatory genes. Given these physiological processes, it appears plausible that OSAS, obesity and poor sleep appear to be highly interrelated.

The results of one study [70] showed that IL-6, triglycerides, and AHI were positively associated with TNF- $\alpha$, while sex, ghrelin and total cholesterol had a negative association. Further, postmenopausal women had higher TNF- $\alpha$ levels than those of premenopausal women [70]. One study showed that higher TNF- $\alpha$ levels were significantly related to some neurocognitive deficits in children with OSAS [14].

Next, TNF- $\alpha$ appears to mediate both a somnogenic activity and fatigue related to excessive daytime somnolence in obese patients with OSAS [14,28,30]. TNF- $\alpha$ levels were related to the severity of OSAS [31]. One study reported that BMI was weakly related to TNF- $\alpha$ levels [32]. However, Kanbay et al. [41] showed that in individuals with OSAS and obesity serum TNF- $\alpha$ levels were significantly higher than those without obesity. Not surprisingly, there was also a positive albeit modest correlation (r: 0.181; $p$ : 0.034) between higher BMI scores and higher TNF- $\alpha$ levels [16].

As regards AHI and TNF- $\alpha$ levels, Kanbay et al. [41] and others [16,78] reported a significant positive correlation between a higher AHI and higher serum TNF- $\alpha$ levels.

Next, Minoguchi et al. [16] reported in their meta-analysis higher plasma and serum TNF- $\alpha$ levels in adults, compared to non-adults.

Despite the novelty of the results, the following limitations should be considered: (1) In all studies, results have not been adjusted for possible confounding factors such as obesity, smoking, or alcohol consumption. (2) The results of the funnel plots showed a publication bias across the studies; it follows that a systematic bias in the data presentation cannot be ruled out. (3) Studies with a small sample size (less than100 cases) had an inadequate power to detect possibly meaningful associations. (4) There was a high heterogeneity among studies in some analyses. (5) Studies reported different cut-off AHI values, which made comparisons between the studies difficult. (6) In some studies, TNF- $\alpha$ levels were considered as secondary outcome. (7) In some studies, the existence of mixed ethnicities might have blurred the associations between the ethnicity and TNF- $\alpha$ levels.

By contrast, the strengths of the meta-analysis were as follows: (1) There were sufficient studies to allow the subgroup analyses. (2) The sensitivity analysis showed a stability of the results. (3) The studies written in other languages than English were included in the meta-analysis. 


\section{Conclusions}

The result of the meta-analysis and meta-regression confirmed that compared to healthy controls, individuals with OSAS (adults) had significant higher serum/plasma TNF- $\alpha$ levels, whereas for children with OSAS, this pattern of results was observed for serum TNF- $\alpha$ levels, but not for plasma TNF- $\alpha$ levels. Last, the results of the present meta-analysis showed that elevated TNF- $\alpha$ levels in individuals with OSAS appeared to be related to the severity of the disease. Future studies might investigate if and to what extent interventions on OSAS (e.g., using CPAP devices) favorably impact on TNF- $\alpha$ levels and possibly also on weight regulation.

Author Contributions: Conceptualization, M.M.I and M.S.; methodology, M.S.; software, M.S.; validation, M.M.I. and S.B.; formal analysis, M.S.; investigation, M.E and D.S.B.; resources, S.B.; data curation, M.S.; writing-original draft preparation, S.B.; writing-review and editing, M.S., H.K., M.E., D.S.B. and S.B.; visualization, H.K.; supervision, M.M.I.; project administration, S.B.; funding acquisition, M.M.I. All authors have read and agreed to the published version of the manuscript.

Funding: This research was funded by Kermanshah University of Medical Sciences grant number (980764) and the APC was funded by University of Basel.

Acknowledgments: This work was performed in partial fulfillment of the requirements for a doctorate degree in General Dentistry (Mehrdad Emami), in the Faculty of Dentistry, Kermanshah University of Medical Sciences, Kermanshah, Iran. This study was funded by the Research Council of Kermanshah University of Medical Sciences.

Conflicts of Interest: The authors declare no conflict of interest.

\section{References}

1. Young, T.; Palta, M.; Dempsey, J.; Skatrud, J.; Weber, S.; Badr, S. The Occurrence of Sleep-Disordered Breathing among Middle-Aged Adults. N. Engl. J. Med. 1993, 328, 1230-1235. [CrossRef] [PubMed]

2. Punjabi, N.M.; Sorkin, J.D.; Katzel, L.I.; Goldberg, A.P.; Schwartz, A.R.; Smith, P.L. Sleep-disordered Breathing and Insulin Resistance in Middle-aged and Overweight Men. Am. J. Respir. Crit. Care Med. 2002, 165, 677-682. [CrossRef]

3. Tufik, S.; Santos-Silva, R.; Taddei, J.A.; Bittencourt, L.R.A. Obstructive Sleep Apnea Syndrome in the Sao Paulo Epidemiologic Sleep Study. Sleep Med. 2010, 11, 441-446. [CrossRef]

4. Bradley, T.D.; Floras, J.S. Obstructive sleep apnoea and its cardiovascular consequences. Lancet 2009, 373, 82-93. [CrossRef]

5. Panchasara, B.; Poots, A.J.; Davies, G. Are the Epworth Sleepiness Scale and Stop-Bang model effective at predicting the severity of obstructive sleep apnoea (OSA); in particular OSA requiring treatment? Eur. Arch. Oto-Rhino-Laryngol. 2017, 274, 4233-4239. [CrossRef] [PubMed]

6. Farney, R.J.; Walker, B.S.; Snow, G.L.; Walker, J.M.; Farney, R.M. The STOP-Bang Equivalent Model and Prediction of Severity of Obstructive Sleep Apnea: Relation to Polysomnographic Measurements of the Apnea/Hypopnea Index. J. Clin. Sleep Med. 2011, 7, 459-465. [CrossRef] [PubMed]

7. Lim, D.C.; I Pack, A. Obstructive Sleep Apnea: Update and Future. Annu. Rev. Med. 2017, 68, 99-112. [CrossRef]

8. Gozal, D.; Kheirandish-Gozal, L. The multiple challenges of obstructive sleep apnea in children: morbidity and treatment. Curr. Opin. Pediatr. 2008, 20, 654-658. [CrossRef]

9. Pedrosa, R.P.; Barros, I.M.L.; Drager, L.F.; Bittencourt, M.S.; Medeiros, A.K.L.; Carvalho, L.L.; Lustosa, T.C.; Carvalho, M.M.B.; Ferreira, M.N.L.; Lorenzi-Filho, G.; et al. OSA Is Common and Independently Associated With Hypertension and Increased Arterial Stiffness in Consecutive Perimenopausal Women. Chest 2014, 146, 66-72. [CrossRef]

10. Drager, L.F.; Togeiro, S.M.; Polotsky, V.Y.; Lorenzi-Filho, G. Obstructive Sleep Apnea: a cardiometabolic risk in obesity and the metabolic syndrome. J. Am. Coll. Cardiol. 2013, 62, 569-576. [CrossRef]

11. Epstein, L.J.; Kristo, D.; Strollo, P.J.; Friedman, N.; Malhotra, A.; Patil, S.P.; Ramar, K.; Rogers, R.; Schwab, R.J.; Weaver, E.M.; et al. Clinical Guideline for the Evaluation, Management and Long-term Care of Obstructive Sleep Apnea in Adults. J. Clin. Sleep Med. 2009, 5, 263-276. [PubMed]

12. Cawthorn, W.P.; Sethi, J.K. TNF- $\alpha$ and adipocyte biology. FEBS lett. 2008, 582, 117-131. [CrossRef] [PubMed] 
13. Popa, C.; Netea, M.G.; Van Riel, P.L.C.M.; Van Der Meer, J.W.M.; Stalenhoef, A.F.H. The role of TNF- $\alpha$ in chronic inflammatory conditions, intermediary metabolism, and cardiovascular risk. J. Lipid Res. 2007, 48, 751-762. [CrossRef] [PubMed]

14. Huang, Y.-S.; Guilleminault, C.; Hwang, F.-M.; Cheng, C.; Lin, C.-H.; Li, H.-Y.; Lee, L.-A. Inflammatory cytokines in pediatric obstructive sleep apnea. Medicine 2016, 95, e4944. [CrossRef]

15. Lavie, L. Obstructive sleep apnoea syndrome - an oxidative stress disorder. Sleep Med. Rev. 2003, 7, 35-51. [CrossRef]

16. Minoguchi, K.; Tazaki, T.; Yokoe, T.; Minoguchi, H.; Watanabe, Y.; Yamamoto, M.; Adachi, M. Elevated Production of Tumor Necrosis Factor- $\alpha$ by Monocytes in Patients With Obstructive Sleep Apnea Syndrome. Chest 2004, 126, 1473-1479. [CrossRef]

17. Nadeem, R.; Molnar, J.; Madbouly, E.M.; Nida, M.; Aggarwal, S.; Sajid, H.; Naseem, J.; Loomba, R. Serum Inflammatory Markers in Obstructive Sleep Apnea: A Meta-Analysis. J. Clin. Sleep Med. 2013, 9, 1003-1012. [CrossRef]

18. Wang, J.; Yu, W.; Gao, M.; Zhang, F.; Gu, C.; Yu, Y.; Wei, Y. Impact of Obstructive Sleep Apnea Syndrome on Endothelial Function, Arterial Stiffening, and Serum Inflammatory Markers: An Updated Meta-analysis and Metaregression of 18 Studies. J. Am. Hear. Assoc. 2015, 4, e002454. [CrossRef]

19. Moher, D.; Shamseer, L.; Clarke, M.; Ghersi, D.; Liberati, A.; Petticrew, M.; Shekelle, P.G.; Stewart, L.A. Preferred reporting items for systematic review and meta-analysis protocols (PRISMA-P) 2015 statement. Syst. Rev. 2015, 4, 1. [CrossRef]

20. Wells, G.; Shea, B.; O'Connell, D.; Peterson, J.; Welch, V.; Losos, M.; Tugwell, P. The Newcastle-Ottawa Scale (NOS) for Assessing the Quality of Non-Randomized Studies in Meta-Analysis. 2018. Available online: http://www.ohri.ca/programs/clinical_epidemiology/oxford.asp (accessed on 12 May 2017).

21. Zintzaras, E.; Hadjigeorgiou, G.M. The role of G196A polymorphism in the brain-derived neurotrophic factor gene in the cause of Parkinson's disease: a meta-analysis. J. Hum. Genet. 2005, 50, 560-566. [CrossRef]

22. Higgins, J.P.T.; Thompson, S.G. Quantifying heterogeneity in a meta-analysis. Stat. Med. 2002, 21, 1539-1558. [CrossRef] [PubMed]

23. Begg, C.B.; Mazumdar, M. Operating Characteristics of a Rank Correlation Test for Publication Bias. Biometrics 1994, 50, 1088. [CrossRef]

24. Egger, M.; Smith, G.D.; Schneider, M.; Minder, C. Bias in meta-analysis detected by a simple, graphical test. BMJ 1997, 315, 629-634. [CrossRef] [PubMed]

25. Duval, S.; Tweedie, R.L. Trim and fill: A simple funnel-plot-based method of testing and adjusting for publication bias in meta-analysis. Biometrics 2000, 56, 455-463. [CrossRef] [PubMed]

26. Wan, X.; Wang, W.; Liu, J.; Tong, T. Estimating the sample mean and standard deviation from the sample size, median, range and/or interquartile range. BMC Med. Res. Methodol. 2014, 14, 135. [CrossRef]

27. Ghiciuc, C.M.; Dima-Cozma, L.C.; Bercea, R.M.; Lupușoru, C.E.; Mihaescu, T.; Cozma, S.; Patacchioli, F.R. Imbalance in the diurnal salivary testosterone/cortisol ratio in men with severe obstructive sleep apnea: an observational study. Braz. J. Otorhinolaryngol. 2016, 82, 529-535. [CrossRef]

28. Vgontzas, A.N.; Papanicolaou, D.A.; Bixler, E.O.; Kales, A.; Tyson, K.; Chrousos, G.P. Elevation of plasma cytokines in disorders of excessive daytime sleepiness: role of sleep disturbance and obesity. J. Clin. Endocrinol. Metab. 1997, 82, 1313-1316. [CrossRef]

29. Huiguo, L.; Jin, L.; Shengdao, X.; Guanxin, S.; Zhenxiang, Z.; Yongjian, X. The change of interleukin-6 and tumor necrosis factor in patients with obstructive sleep apnea syndrome. J. Tongji Med. Univ. 2000, 20, 200-202. [CrossRef]

30. Vgontzas, A.N.; Papanicolaou, D.A.; Bixler, E.O.; Hopper, K.; Lotsikas, A.; Lin, H.-M.; Kales, A.; Chrousos, G.P. Sleep apnea and daytime sleepiness and fatigue: relation to visceral obesity, insulin resistance, and hypercytokinemia. J. Clin. Endocrinol. Metab. 2000, 85, 1151-1158. [CrossRef]

31. Ciftci, T.U.; Kokturk, O.; Bukan, N.; Bilgihan, A. The relationship between serum cytokine levels with obesity and obstructive sleep apnea syndrome. Cytokine 2004, 28, 87-91. [CrossRef]

32. Imagawa, S.; Yamaguchi, Y.; Ogawa, K.; Obara, N.; Suzuki, N.; Yamamoto, M.; Nagasawa, T. Interleukin-6 and Tumor Necrosis Factor- $\alpha$ in Patients with Obstructive Sleep Apnea-Hypopnea Syndrome. Respiration 2004, 71, 24-29. [CrossRef] [PubMed] 
33. Tazaki, T.; Minoguchi, K.; Yokoe, T.; Samson, K.T.R.; Minoguchi, H.; Tanaka, A.; Watanabe, Y.; Adachi, M. Increased Levels and Activity of Matrix Metalloproteinase-9 in Obstructive Sleep Apnea Syndrome. Am. J. Respir. Crit. Care Med. 2004, 170, 1354-1359. [CrossRef] [PubMed]

34. Ryan, S.; Taylor, C.T.; McNicholas, W.T. Selective Activation of Inflammatory Pathways by Intermittent Hypoxia in Obstructive Sleep Apnea Syndrome. Circulation 2005, 112, 2660-2667. [CrossRef] [PubMed]

35. Kobayashi, K.; Nishimura, Y.; Shimada, T.; Yoshimura, S.; Funada, Y.; Satouchi, M.; Yokoyama, M. Effect of Continuous Positive Airway Pressure on Soluble CD40 Ligand in Patients With Obstructive Sleep Apnea Syndrome. Chest 2006, 129, 632-637. [CrossRef]

36. Ryan, S.; Taylor, C.T.; McNicholas, W.T. Predictors of Elevated Nuclear Factor-kB-dependent Genes in Obstructive Sleep Apnea Syndrome. Am. J. Respir. Crit. Care Med. 2006, 174, 824-830. [CrossRef] [PubMed]

37. Tam, C.S.; Wong, M.; McBain, R.; Bailey, S.; Waters, K.A. Inflammatory measures in children with obstructive sleep apnoea. J. Paediatr. Child Heal. 2006, 42, 277-282. [CrossRef]

38. Bravo, M.D.L.P.; Serpero, L.D.; Barceló, A.; Barbé, F.; Agusti, A.; Gozal, D. Inflammatory proteins in patients with obstructive sleep apnea with and without daytime sleepiness. Sleep Breath. 2007, 11, 177-185. [CrossRef]

39. Arias, M.; García-Río, F.; Alonso-Fernández, A.; Hernanz, A.; Hidalgo, R.; Martínez-Mateo, V.; Bartolomé, S.; Rodríguez-Padial, L. CPAP decreases plasma levels of soluble tumour necrosis factor- $\alpha$ receptor 1 in obstructive sleep apnoea. Eur. Respir. J. 2008, 32, 1009-1015. [CrossRef]

40. Constantinidis, J.; Ereliadis, S.; Angouridakis, N.; Konstantinidis, I.; Vital, V.; Angouridaki, C. Cytokine changes after surgical treatment of obstructive sleep apnoea syndrome. Eur. Arch. Oto-Rhino-Laryngol. 2008, 265, 1275-1279. [CrossRef]

41. Kanbay, A.; Kokturk, O.; Ciftci, T.U.; Tavil, Y.; Bukan, N. Comparison of Serum Adiponectin and Tumor Necrosis Factor-Alpha Levels between Patients with and without Obstructive Sleep Apnea Syndrome. Respiration 2008, 76, 324-330. [CrossRef]

42. Li, A.M.; Lam, H.S.; Chan, M.H.M.; So, H.K.; Ng, S.K.; Chan, I.H.S.; Lam, C.W.K.; Wing, Y.K. Inflammatory cytokines and childhood obstructive sleep apnoea. Ann. Acad. Med. Singap. 2008, 37.

43. Tomiyama, H.; Okazaki, R.; Inoue, D.; Ochiai, H.; Shiina, K.; Takata, Y.; Hashimoto, H.; Yamashina, A. Link between obstructive sleep apnea and increased bone resorption in men. Osteoporos. Int. 2008, 19, 1185-1192. [CrossRef] [PubMed]

44. Carneiro, G.; Togeiro, S.M.; Ribeiro-Filho, F.F.; Truksinas, E.; Ribeiro, A.B.; Zanella, M.T.; Tufik, S. Continuous Positive Airway Pressure Therapy Improves Hypoadiponectinemia in Severe Obese Men With Obstructive Sleep Apnea Without Changes in Insulin Resistance. Metab. Syndr. Relat. Disord. 2009, 7, 537-542. [CrossRef] [PubMed]

45. Li, Y.; Chongsuvivatwong, V.; Geater, A.F.; Liu, A. Exhaled breath condensate cytokine level as a diagnostic tool for obstructive sleep apnea syndrome. Sleep Med. 2009, 10, 95-103. [CrossRef]

46. Thomopoulos, C.; Tsioufis, C.; Dimitriadis, K.; Tsiachris, D.; Tousoulis, D.; Manolis, A.; Alchanatis, M.; Kallikazaros, I.; Stefanadis, C. Obstructive sleep apnoea syndrome is associated with enhanced sub-clinical inflammation and asymmetric dimethyl-arginine levels in hypertensives. J. Hum. Hypertens. 2008, 23, 65-67. [CrossRef] [PubMed]

47. Sahlman, J.; Miettinen, K.; Peuhkurinen, K.; Seppä, J.; Peltonen, M.; Herder, C.; Punnonen, K.; Vanninen, E.; Gylling, H.; Partinen, M.; et al. The activation of the inflammatory cytokines in overweight patients with mild obstructive sleep apnoea. J. Sleep Res. 2009, 19, 341-348. [CrossRef] [PubMed]

48. Steiropoulos, P.; Papanas, N.; Nena, E.; Antoniadou, M.; Serasli, E.; Papoti, S.; Hatzizisi, O.; Kyriazis, G.; Tzouvelekis, A.; Maltezos, E.; et al. Inflammatory Markers in Middle-Aged Obese Subjects: Does Obstructive Sleep Apnea Syndrome Play a Role? Mediat. Inflamm. 2010, 2010, 1-6. [CrossRef]

49. Saraç, F.; Basoglu, O.K.; Gunduz, C.; Bayrak, H.; Avci, C.B.; Akcicek, F. Association of osteopontin and tumor necrosis factor-? levels with insulin resistance in obese patients with obstructive sleep apnea syndrome. J. Endocrinol. Investig. 2010, 34, 528-533.

50. Fornadi, K.; Lindner, A.; Czira, M.E.; Szentkirályi, A.; Lazar, A.S.; Zoller, R.; Turanyi, C.Z.; Veber, O.; Novak, M.; Mucsi, I.; et al. Lack of association between objectively assessed sleep disorders and inflammatory markers among kidney transplant recipients. Int. Urol. Nephrol. 2011, 44, 607-617. [CrossRef]

51. Medeiros, C.A.M.; De Bruin, V.M.S.; Andrade, G.M.; Coutinho, W.M.; De Castro-Silva, C.; De Bruin, P.F.C. Obstructive sleep apnea and biomarkers of inflammation in ischemic stroke. Acta Neurol. Scand. 2011, 126, 17-22. [CrossRef] 
52. Qian, X.; Yin, T.; Li, T.; Kang, C.; Guo, R.; Sun, B.; Liu, C. High Levels of Inflammation and Insulin Resistance in Obstructive Sleep Apnea Patients with Hypertension. Inflammation 2012, 35, 1507-1511. [CrossRef] [PubMed]

53. Alexopoulos, E.I.; Theologi, V.; Malakasioti, G.; Maragozidis, P.; Tsilioni, I.; Chrousos, G.; Gourgoulianis, K.; Kaditis, A.G. Obstructive Sleep Apnea, Excessive Daytime Sleepiness, and Morning Plasma TNF- $\alpha$ Levels in Greek Children. Sleep 2013, 36, 1633-1638. [CrossRef] [PubMed]

54. Chen, P.-C.; Guo, C.-H.; Tseng, C.-J.; Wang, K.-C.; Liu, P.-J. Blood trace minerals concentrations and oxidative stress in patients with obstructive sleep apnea. J. Nutr. Heal. Aging 2013, 17, 639-644. [CrossRef] [PubMed]

55. Chu, L.; Li, Q. The evaluation of adenotonsillectomy on TNF- $\alpha$ and IL-6 levels in obese children with obstructive sleep apnea. Int. J. Pediatr. Otorhinolaryngol. 2013, 77, 690-694. [CrossRef]

56. Hargens, T.A.; Guill, S.G.; Kaleth, A.S.; Nickols-Richardson, S.M.; E Miller, L.; Zedalis, D.; Gregg, J.M.; Gwazdauskas, F.; Herbert, W.G. Insulin resistance and adipose-derived hormones in young men with untreated obstructive sleep apnea. Sleep Breath. 2012, 17, 403-409. [CrossRef]

57. Matos, G.; Hirotsu, C.; Alvarenga, T.A.; Cintra, F.D.; Bittencourt, L.R.A.; Tufik, S.; Andersen, M.L. The association between TNF- $\alpha$ and erectile dysfunction complaints. Andrology 2013, 1, 872-878. [CrossRef]

58. Luo, Q.; Yang, D.; Liu, Z. Plasma ghrelin and pro-inflammatory markers in patients with obstructive sleep apnea and stable coronary heart disease. Med. Sci. Monit. 2013, 19, 251-256. [CrossRef]

59. Ciccone, M.; Scicchitano, P.; Zito, A.; Cortese, F.; Boninfante, B.; Falcone, V.A.; Quaranta, V.N.; Ventura, V.A.; Zucano, A.; Di Serio, F.; et al. Correlation between Inflammatory Markers of Atherosclerosis and Carotid Intima-Media Thickness in Obstructive Sleep Apnea. Molecules 2014, 19, 1651-1662. [CrossRef]

60. Sun, L.; Chen, R.; Wang, J.; Zhang, Y.-L.; Li, J.; Peng, W.; Liu, C. Association between inflammation and cognitive function and effects of continuous positive airway pressure treatment in obstructive sleep apnea hypopnea syndrome. Zhonghua yi xue za zhi 2014, 94, 3483-3487.

61. Doğan, F.Ü.; Yosunkaya, Ş.; Okur, H.K.; Can, Ü. Relationships between Obstructive Sleep Apnea Syndrome, Continuous Positive Airway Pressure Treatment, and Inflammatory Cytokines. Sleep Disord. 2014, 2014, 1-6. [CrossRef]

62. Chen, B.; Zhang, W.; Chen, Y.; Hu, C.; Bian, H.; He, J.; Ji, L.; Zhu, S. Association of obstructive sleep apnea hypopnea syndrome with carotid atherosclerosis and the efficacy of continuous positive airway pressure treatment. Zhonghua yi xue za zhi 2015, 95, 2791-2795.

63. De Santis, S.; Cambi, J.; Tatti, P.; Bellussi, L.; Passali, D. Changes in ghrelin, leptin and pro-inflammatory cytokines after therapy in Obstructive Sleep Apnea Syndrome (OSAS) patients. Otolaryngol. Polska 2015, 69, 1-10. [CrossRef] [PubMed]

64. Jiang, H.; Cao, H.; Wang, P.; Liu, W.; Cao, F.; Chen, J. Tumour necrosis factor- $\alpha$ /interleukin-10 ratio in patients with obstructive sleep apnoea hypopnoea syndrome. J. Laryngol. Otol. 2014, 129, 73-78. [CrossRef] [PubMed]

65. Thunström, E.; Glantz, H.; Fu, M.; Yucel-Lindberg, T.; Petzold, M.; Lindberg, K.; Peker, Y. Increased Inflammatory Activity in Nonobese Patients with Coronary Artery Disease and Obstructive Sleep Apnea. Sleep 2015, 38, 463-471. [CrossRef]

66. Gaines, J.; Vgontzas, A.N.; Fernandez-Mendoza, J.; Calhoun, S.L.; He, F.; Liao, D.; Sawyer, M.; Bixler, E.O. Inflammation mediates the association between visceral adiposity and obstructive sleep apnea in adolescents. Am. J. Physiol. Metab. 2016, 311, E851-E858. [CrossRef]

67. Lin, C.-C.; Liaw, S.-F.; Chiu, C.-H.; Chen, W.-J.; Lin, M.-W.; Chang, F.-T. Effects of nasal CPAP on exhaled SIRT1 and tumor necrosis factor- $\alpha$ in patients with obstructive sleep apnea. Respir. Physiol. Neurobiol. 2016, 228, 39-46. [CrossRef]

68. Nizam, N.; Basoglu, O.K.; Taşbakan, M.S.; Lappin, D.F.; Buduneli, N.; Başoğlu, Ö.K. Is there an association between obstructive sleep apnea syndrome and periodontal inflammation? Clin. Oral Investig. 2015, 20, 659-668. [CrossRef]

69. Vicente, E.; Marin, J.M.; Carrizo, S.J.; Osuna, C.S.; González, R.; Marin-Oto, M.; Forner, M.; Vicente, P.; Cubero, P.; Gil, A.V.; et al. Upper airway and systemic inflammation in obstructive sleep apnoea. Eur. Respir. J. 2016, 48, 1108-1117. [CrossRef]

70. Hirotsu, C.; Albuquerque, R.G.; Nogueira, H.; Hachul, H.; Bittencourt, L.R.A.; Tufik, S.; Andersen, M.L. The relationship between sleep apnea, metabolic dysfunction and inflammation: The gender influence. Brain, Behav. Immun. 2017, 59, 211-218. [CrossRef] 
71. Ji, Y.-L.; Xue, J.; Xu, J.; Zhou, Z.; Ji, Y. Efficacy of continuous positive airway pressure treatment in treating obstructive sleep apnea hypopnea syndrome associated with carotid arteriosclerosis. Exp. Ther. Med. 2017, 14, 6176-6182. [CrossRef]

72. Jin, F.; Liu, J.; Zhang, X.; Cai, W.; Zhang, Y.; Zhang, W.; Yang, J.; Lu, G.; Zhang, X. Effect of continuous positive airway pressure therapy on inflammatory cytokines and atherosclerosis in patients with obstructive sleep apnea syndrome. Mol. Med. Rep. 2017, 16, 6334-6339. [CrossRef] [PubMed]

73. Smith, D.; Hossain, M.; Hura, A.; Huang, G.; McConnell, K.; Ishman, S.L.; Amin, R. Inflammatory Milieu and Cardiovascular Homeostasis in Children With Obstructive Sleep Apnea. Sleep 2017, 40. [CrossRef] [PubMed]

74. Zhang, Z.; Wang, C. Immune status of children with obstructive sleep apnea/hypopnea syndrome. Pak. J. Med. Sci. 2017, 33, 195-199. [CrossRef] [PubMed]

75. Bozic, J.; Borovac, J.A.; Galic, T.; Kurir, T.T.; Supe-Domic, D.; Đogaš, Z. Adropin and Inflammation Biomarker Levels in Male Patients With Obstructive Sleep Apnea: A Link With Glucose Metabolism and Sleep Parameters. J. Clin. Sleep Med. 2018, 14, 1109-1118. [CrossRef] [PubMed]

76. Kong, Y.; Li, Z.; Tang, T.; Wu, H.; Liu, J.; Gu, L.; Zhao, T.; Huang, Q. The level of lipopolysaccharide-binding protein is elevated in adult patients with obstructive sleep apnea. BMC Pulm. Med. 2018, 18, 90. [CrossRef] [PubMed]

77. Rogers, V.E.; Bollinger, M.E.; Tulapurkar, M.E.; Zhu, S.; Hasday, J.D.; Pereira, K.D.; Scharf, S.M. Inflammation and asthma control in children with comorbid obstructive sleep apnea. Pediatr. Pulmonol. 2018, 53, 1200-1207. [CrossRef]

78. Ming, H.; Tian, A.; Liu, B.; Hu, Y.; Liu, C.; Chen, R.; Cheng, L. Inflammatory cytokines tumor necrosis factor- $\alpha$, interleukin-8 and sleep monitoring in patients with obstructive sleep apnea syndrome. Exp. Ther. Med. 2019, 17, 1766-1770. [CrossRef]

79. Tang, T.; Huang, Q.; Liu, J.; Zhou, X.; Du, J.; Wu, H.; Li, Z. Oxidative stress does not contribute to the release of proinflammatory cytokines through activating the Nod-like receptor protein 3 inflammasome in patients with obstructive sleep apnoea. Sleep Breath 2018, 23, 535-542. [CrossRef]

80. Galati, D.; Zanotta, S.; Canora, A.; Polistina, G.E.; Nicoletta, C.; Ghinassi, G.; Ciasullo, E.; Bocchino, M. Severe depletion of peripheral blood dendritic cell subsets in obstructive sleep apnea patients: A new link with cancer? Cytokine 2019, 125, 154831. [CrossRef]

81. Ferrari, R. THE role of TNF in cardiovascular disease. Pharmacol. Res. 1999, 40, 97-105. [CrossRef] [PubMed]

82. Matthys, P.; Billiau, A. Cytokines and cachexia. Nutrition 1997, 13, 763-770. [CrossRef]

83. Drager, L.F.; Polotsky, V.Y.; Lorenzi-Filho, G. Obstructive sleep apnea: an emerging risk factor for atherosclerosis. Chest 2011, 140, 534-542. [CrossRef] [PubMed]

84. Naldini A, Carraro F, Silvestri S, Bocci V. Hypoxia affects cytokine production and proliferative responses by human peripheral mononuclear cells. J. Cell. Physiol. 1997, 173, 335-342. [CrossRef]

85. Hempel, S.L.; Monick, M.M.; Hunninghake, G.W. Effect of hypoxia on release of IL-1 and TNF by human alveolar macrophages. Am. J. Respir. Cell Mol. Boil. 1996, 14, 170-176. [CrossRef] [PubMed]

86. IImani, M.M.; Sadeghi, M.; Khazaie, H.; Emani, M.; Sadeghi Bahmani, D.; Brand, S. Evaluation of serum and plasma interleukin-6 levels in obstructive sleep apnea syndrome (OSAS): A meta-analysis and meta-regression. Front. Immunol. 2020, in press.

87. Cameron, F.L.; Altowati, M.A.; Rogers, P.; McGrogan, P.; Anderson, N.; Bisset, W.M.; Ahmed, S.F.; Wilson, D.C.; Russell, R.K. Disease Status and Pubertal Stage Predict Improved Growth in Antitumor Necrosis Factor Therapy for Pediatric Inflammatory Bowel Disease. J. Pediatr. Gastroenterol. Nutr. 2017, 64, 47-55. [CrossRef] [PubMed]

88. Han, Y.; Liu, Y.; Zhao, Z.; Zhen, S.; Chen, J.; Ding, N.; Ma, Y.; Wen, D. Does Physical Activity-Based Intervention Improve Systemic Proinflammatory Cytokine Levels in Overweight or Obese Children and Adolescents? Insights from a Meta-Analysis of Randomized Control Trials. Obes Facts 2019, 12, 653-668. [CrossRef]

(C) 2020 by the authors. Licensee MDPI, Basel, Switzerland. This article is an open access article distributed under the terms and conditions of the Creative Commons Attribution (CC BY) license (http://creativecommons.org/licenses/by/4.0/). 